This PDF is a selection from a published volume from the National Bureau of Economic Research

Volume Title: Law and Employment: Lessons from Latin American and the Caribbean

Volume Author/Editor: James J. Heckman and Carmen Pagés, editors

Volume Publisher: University of Chicago Press

Volume ISBN: 0-226-32282-3

Volume URL: http://www.nber.org/books/heck04-1

Conference Date: November 16-17, 2000

Publication Date: August 2004

Title: The Effects of Labor Market Regulations on Employment Decisions by Firms. Empirical Evidence for Argentina

Author: Guillermo Mondino, Silvia Montoya

URL: http://www.nber.org/chapters/c10073 


\title{
The Effects of Labor Market Regulations on Employment Decisions by Firms Empirical Evidence for Argentina
}

\author{
Guillermo Mondino and Silvia Montoya
}

\subsection{Introduction}

The 1990s saw vast structural transformations in Argentina. After half a century of low growth, high and volatile inflation, and stagnating living standards, Argentina introduced many reforms that yielded remarkably strong growth while inflation dwindled. The change of "economic paradigm" led to a number of behavioral changes that were reflected in other areas. But perhaps the most striking change took place in the labor market. There, where reforms were moderate, the most noticeable difference appeared. High open unemployment was the outcome. Could it be that the lack of ambitious reforms in labor market practices was behind this unfortunate outcome?

Historically, Argentina's labor market had been characterized by the relative scarcity of unskilled labor. This was reflected in moderate open urban unemployment and in the need to resort, periodically, to foreign labor to cover labor shortages. Wages and other hiring conditions were in keeping with the greater bargaining power that stemmed from excess labor demand. In particular, the dominant economic model limited the need for the economy to reallocate resources. The result was a depressed rate of job creation and, especially, destruction. This made a number of union- and governmentsponsored demands compatible with the opportunities faced by firms. However, low growth and high and accelerating inflation ended up pushing the

Guillermo Mondino is an economist at IERAL de Fundación Mediterránea. Silvia Montoya is an economist at IERAL de Fundación Mediterránea.

We would like to acknowledge the tremendous effort put into this research project by Roger Aliaga. Manuel Willington and Marcos Delprato provided helpful research assistance at different stages of the project. Any remaining errors are our responsibility. 
Table 6.1

Macroeconomics Indicators: 1974-1998

\begin{tabular}{rccccrr}
\hline & $\begin{array}{c}\text { GDP per } \\
\text { Capita } \\
(1)\end{array}$ & $\begin{array}{c}\text { Jobs per } \\
\text { Capita } \\
(2)\end{array}$ & $\begin{array}{c}\text { GDP/Jobs } \\
(3)=(1) /(2)\end{array}$ & $\begin{array}{c}\text { Unemployment } \\
(4)\end{array}$ & $\begin{array}{c}\text { Inflation } \\
\text { Rate }^{\mathrm{b}} \\
(5)\end{array}$ & $\begin{array}{c}\text { Labor } \\
\text { Force }^{\mathrm{c}} \\
(6)\end{array}$ \\
\hline 1974 & 91.9 & 100.9 & 91.1 & 3.3 & 24.2 & 102.9 \\
1980 & 100.0 & 100.0 & 100.0 & 2.6 & 100.8 & 100.0 \\
1985 & 83.9 & 95.6 & 87.8 & 6.1 & 672.2 & 99.2 \\
1988 & 86.7 & 98.2 & 88.3 & 6.3 & 343.0 & 102.8 \\
1989 & 79.4 & 97.2 & 81.7 & 7.6 & 3.079 .5 & 103.5 \\
1990 & 77.0 & 96.3 & 80.0 & 7.5 & $2,314.0$ & 102.3 \\
1991 & 84.1 & 98.4 & 85.5 & 6.5 & 171.7 & 103.5 \\
1992 & 90.9 & 99.2 & 91.6 & 7.0 & 24.9 & 105.8 \\
1993 & 95.0 & 98.5 & 96.5 & 9.6 & 10.6 & 109.9 \\
1994 & 101.3 & 96.3 & 105.2 & 11.5 & 4.2 & 109.4 \\
1995 & 96.1 & 91.9 & 104.6 & 17.5 & 3.4 & 112.1 \\
1997 & 106.6 & 95.1 & 112.1 & 14.9 & 0.5 & 114.4 \\
1998 & 109.8 & 97.6 & 112.5 & 12.8 & 0.9 & 115.1 \\
\hline
\end{tabular}

Source: IERAL database.

Note: Index $1980=100$.

${ }^{a}$ Gran Buenos Aires (GBA).

${ }^{\mathrm{b}}$ Annual rate.

${ }^{\mathrm{c}}$ GBA. Index $1980=100$.

economy into a deep crisis. The far-reaching reforms that followed in the 1990s took place mainly in monetary affairs and in goods and service market behavior, not labor markets. This asymmetry in changes has been cited by many as an underlying factor in the appearance of high unemployment.

Argentina evidenced remarkably stable growth in employment during the 1980s (at 1.1 percent annual rate, barely enough to accommodate population growth) while gross domestic product (GDP) was shrinking (-0.9 percent annually). Conversely, during much of the 1990s GDP growth was not only strong but also quite sustained (on average, 5.2 percent per year during 1990-1998). The behavior of employment, once again, did not match that of GDP (0.9 percent per year; see table 6.1).

Unemployment in the 1990s reached record levels (18.6 percent in 1995) and scored in the double digits after 1994. Movements in demand or supply could explain changes in the rate of unemployment. If labor market regulations were to seriously hinder job creation, they would have to operate on the demand side.

Labor demand dynamics could arise from a number of factors. In particular, given our interest in the potential effect of regulations, it appears crucial to evaluate how movements in labor costs could influence job creation dynamics. The question of whether labor market regulations reduce flexibility is a matter of substantial controversy. Critics claim that strong job rights prevent employers from adjusting to economic fluctuations ( $\mathrm{Lu}-$ cas and Fallon 1991; Oi 1962). It is also alleged that, by inhibiting layoffs 
during downturns, strong job rights reduce the employer's willingness to hire people during recoveries, thus contributing to unemployment. Supporters of strong workers' rights argue that job security provisions have no observable effects.

In Argentina, workers have historically enjoyed strong job rights (including a right to advanced layoff notice and to severance payments). During the 1990s, and following the rapid growth in unemployment, these regulations came under attack. Many argued that the cost equivalent of these provisions had become an increasing nuisance. Figure 6.1 shows an approximation to the cost burden implied by job security provisions split into its three main components: (1) average tenure of formal sector employees; (2) layoffs over labor force; and (3) average wages in the formal sector. ${ }^{1}$ The three panels suggest significant changes in all three components of firms' expected costs. As the economy went deeper into restructuring and reform (1991-1997), regulations became increasingly binding. As mean real wage earnings grew, the probability that a worker would be laid off (approximated by the fraction of layoffs) tripled, while average tenure was cut by 20 percent. $^{2}$

It is possible that increases in regulatory costs had a substantive impact on labor demand. The puzzling increase in output per worker, presented in table 6.1, could be the result of optimizing behavior by firms that attempted to increase output without new hires and looked to save on the (anticipated) growing costs of severance. Output per worker may have grown in part from an increased use of overtime workers.

In this paper we provide some evidence on these issues. We exploit, for the first time, a panel data set that covers over 1,300 manufacturing firms for the period 1990-1996. The panel provides information on employment and hours worked, as well as overtime, wages, and physical production. The data, however, are constrained to a limited sector (manufacturing) and, most important, to a relatively short period of time. Unfortunately, most sizable changes in labor market regulations occurred by the end of 1995 , only a year before the panel was discontinued, making it harder to identify the effects on labor demand. We nevertheless exploit the hours worked/jobs relation to shed some light on labor market dynamics.

We structure the rest of the paper by presenting, in section 6.2 , some selected institutional features of Argentina's labor market that focus on job security regulations and payroll taxes. Section 6.3 considers two important descriptive issues: Who benefits from regulations, and how much do they

1. The fourth component is the legal provision that mandates the number of salaries per years of tenure. Over the two decades, legislative changes focused only on changing the maximum number of salaries that might be paid. Since these changes were minor and are hard to identify for the aggregate labor force, the pattern observed in figure 6.1 should appropriately proxy for severance payments cost.

2. It is very difficult to construct an aggregate proxy for the average severance costs because of the nonlinearity of the severance compensation scheme. 



Fig. 6.1 Expected severance payment-Gran Buenos Aires, 1974-1997 Source: IERAL database.

cost? The evidence is based on Permanent Household Survey (PHS) microdata and identifies the effects on individuals' labor market outcomes stemming from varying regulations. We turn to firm-level dynamic labor demand estimation in section 6.4. We document the dynamic responsiveness of employment and hours to changes in output and labor costs at the firm level. Section 6.5 concludes.

\subsection{Institutional Background}

Argentina's labor market, like those of many developing nations, differs in important ways from those operating in industrial countries. Perhaps 
the most symptomatic differences are the relative importance of selfemployment and informal work practices (defined as those not covered by regulations or contributing to social security). These observations have often been taken as evidence of asphyxiating regulations and steep taxation. Furthermore, and as a natural extension, it is argued that wage formation depends critically on labor market institutions and government regulations such as trade unions, minimum wage laws, job security provisions, and so forth.

There are three layers of binding legal regulations that govern workerfirm relations. They are, in terms of decreasing importance, ${ }^{3}(1)$ the Workers' Statute (Ley de Contrato de Trabajo-20.744) and other general legislation such as superior rank laws, which establish many labor relations rules and the framework for collective bargaining; (2) centralized collective bargaining at the sector level, which operates as a second tier; and (3) firmlevel contracts, which, if they exist, can only build upon the previous two. ${ }^{4}$

Labor regulations also introduce other distortions. Workers' statutes introduce specific job security provisions in the form of expensive firing costs. The statute also restricts hiring by limiting tryout periods. Sick leave, vacations, and pregnancy provisions are also quite generously provided at the most general level. A thirteenth wage is also mandatory and must be paid in halves at midyear and year-end. Similarly, contributions to unionsponsored health programs are required (regardless of whether the services are being used). ${ }^{5}$

\subsubsection{Employment Legislation}

Nonwage labor costs include a number of items other than the usual social security contributions. A number of these costs that arise from different regulations have been the subject of changes over the last few years. A basic characterization of labor regulations and taxes appears in the following sections.

\section{Legal Framework for Individual Contracts}

The most important provisions are types of contracts; job security provisions; and working hours, holidays, and sick leave.

Of the types of contracts, the most prevalent is the indeterminate duration type, or lifetime contract, which enjoys the highest degree of protection. Dismissal, if it occurs, is always presumed to be unfair. Some types of temporary contracts were allowed and used previous to 1995, but they were

3. That is, if contracts are signed taking into consideration agreements at level (3) they cannot be in disagreement with terms established at level (2), much less with those at level (1). In other words, level (1) sets a minimum standard.

4. Some areas are outside the scope of the general laws. In those cases the collective agreement is set up as a statute with rank of law. Examples are the rural sector worker statute, the journalist statute, and others.

5. An additional source of cost is the contribution of active workers to the pensioners' health program (PAMI). 
considered exceptional, while permanent arrangements were the rule. In December 1995 some reforms were introduced that added new types of fixed-term contracts. Their main features were lower severance payments, an extended tryout period with reduced social security contributions, and other benefits to make them more attractive for employers. This regulatory change added a new dimension to an already complex labor market. Starting in 1999 those contracts were made illegal. ${ }^{6}$

Job security provisions include mandatory written advance notice before a firing and severance payments. Costs increase with tenure (see figure 6A.1).

There are limited opportunities for micro-level decisions concerning the distribution of hours worked, overtime, night work, and vacation periods. There is generous maternity and sick leave. ${ }^{7}$

\section{Collective Labor Laws}

The basic laws are union (called professional associations) laws; sector wage bargaining has been the predominant mode of bargaining in Argentina, framed as collective agreements. As previously mentioned, collective agreements often set floors, which can only be built upon, at lower levels of negotiations.

The interaction of the two laws defines a sticky situation (see figure 6.2). On the one hand, collective agreements delimit the basic features of contracts. On the other hand, union law identifies those participants in any collective bargain and defines conditions under which anyone else other than the sectoral/regional level (third grade) association could sign a collective agreement. ${ }^{8}$ Together they have important implications for the functioning of markets and industrial relations. For instance, regional shocks cannot be easily accommodated since they cut across many sectors but, not being widespread enough, will not trigger renegotiations at sector-specific levels.

6. The changes introduced in 1995 were introduced "at the margin" and were aimed at solving the increasingly complicated employment outlook as well as adding some flexibility to a very sclerotic market. In particular, the choice was to enhance the flexibility of hirings for new cohorts of workers that entered the market from 1995 onward. The number of fixed-term contracts rose from less than 1 percent of formal wage earners in 1995 to almost 5 percent by the end of 1998. The steep increase in short-term employment contrasted with moderate growth in total dependent employment. The share of short-run employment (fixed-term plus trial period contracts) reached about 10 percent of total formal employment.

7. Sometimes the restrictions arise from the law; others arise from the collective agreements. The problem is that many of these agreements date from a period of extensive government presence in the economy. It is one thing for sectorial-level unions to negotiate with private firms subject to strict budget constraints and quite another to do it with a government-owned corporation with soft budget constraints. The banking-sector contract is an example of this problem, among many others.

8. The Ley de Asociaciones Profesionales defines the structure of the union sector. The third grade association of national range, the most forceful ones, are the only ones who can sign a collective agreement and who, eventually, can give authorization for decentralized negotiations. 




Fig. 6.2 Labor law mechanism

Source: IERAL database.

That is, in spite of individual firms' and workers' having strong incentives to revise their contracts, regulations make such revisions illegal. Business participants report that this has, effectively, been one of the greatest restrictions to renegotiations of contracts, affecting mostly smaller and remote firms and workers with the least say in centralized negotiations.

The problem is compounded because of the automatic renewal clause, called ultractividad. This clause automatically extends the terms of an earlier collective agreement if the parties do not reach a new one, which occurs if any one party is in disagreement.

\section{Social Security}

Social security consists of pension law, family allowances, workers' compensation laws, health care funds ("obras sociales"), unemployment insurance, and the pensioners' health care scheme (PAMI). ${ }^{9}$

Table 6.2 shows the current picture of labor costs in Argentina for a lifetime contract. ${ }^{10}$

In the 1990s reforms concentrated on two basic aspects: social security

9. Workers' compensation was reformed in July 1996, when a new system was introduced with costs that averaged 2.5 percent of gross wages. The previous scheme was highly unfair and arbitrarily opened up opportunities for expensive litigation and corruption. The reformed system introduced mandatory insurance, the organization of a market, and specific limits on the magnitude of compensations. It is widely regarded as a massive improvement over the previous legislation.

10. Since 1995 employers' contributions have been subject to deductions according to region and branch of activity of the firm. 
Nonwage Labor Cost Structure (percentage over gross wage)

\begin{tabular}{|c|c|c|}
\hline Contributions & $\begin{array}{c}\text { Normal } \\
\text { Contract }\end{array}$ & $\begin{array}{l}\text { Share Over } \\
\text { Total Cost }\end{array}$ \\
\hline Pension fund & 27 & 47.4 \\
\hline Employee & 11 & 19.3 \\
\hline Employer & 16 & 28.1 \\
\hline PAMI & 5 & 8.8 \\
\hline Employee & 3 & 5.3 \\
\hline Employer & 2 & 3.5 \\
\hline Family allowances $^{\mathrm{b}}$ & 7.5 & 13.2 \\
\hline Unemployment fund ${ }^{\mathrm{b}}$ & 1.5 & 2.6 \\
\hline Health care scheme & 9 & 15.8 \\
\hline Employee & 3 & 5.3 \\
\hline Employer & 5 & 8.8 \\
\hline Workers' comp ${ }^{\mathrm{b}}$ & 2.5 & 4.4 \\
\hline Social security overall cost & 52.5 & 92.0 \\
\hline Severance payment ${ }^{\mathrm{a}}$ & 5 & 8.8 \\
\hline Advance notice ${ }^{a}$ & 0.5 & 0.9 \\
\hline Employee's cost & 17 & 29.8 \\
\hline Employer's cost & 40 & 70.2 \\
\hline Nonwage labor cost & 57 & 100 \\
\hline
\end{tabular}

Source: IERAL database.

aEstimates: employer's cost.

${ }^{\text {b} E m p l o y e r ' s ~ c o s t . ~}$

and its financing, and the introduction of fixed-term contracts. General dissatisfaction with the costs of the social security scheme triggered a significant reform that became operational in 1994. Workers and firms regard social security contributions as a tax, not deferred compensation. As such, many undertake elusive actions that end up generating inequalities and inefficiencies, favoring a precarious system of labor relationships. ${ }^{11}$

The pension reform was aimed at all workers in the market place. It spurred a transfer of individuals from the pay-as-you-go system onto a newly created fully funded one. The two systems would coexist. Most workers adopted the new system. ${ }^{12}$

11. Figure 6A.2 shows the evolution of social security financing from 1960, the starting period of a more structural social security system. Until 1990 the different programs functioned with great difficulty because of the existence of different institutions performing the same role.

12. Over 60 percent of all covered workers and over 90 percent of new hires belong to the fully funded scheme. A significant difficulty with the original design was finding financing for the transitional phase. Current retirees must be supported via contributions from those who remain in the pay-as-you-go system and through taxes on those in the fully funded one. The high rate of taxation necessary to balance the system became a serious policy issue as it clashed with employment needs. For this reason, in 1994 a system of graduated labor tax reductions was put into place. The reductions were moderated in 1995, because of high fiscal needs, and brought back more aggressively in 1996. 


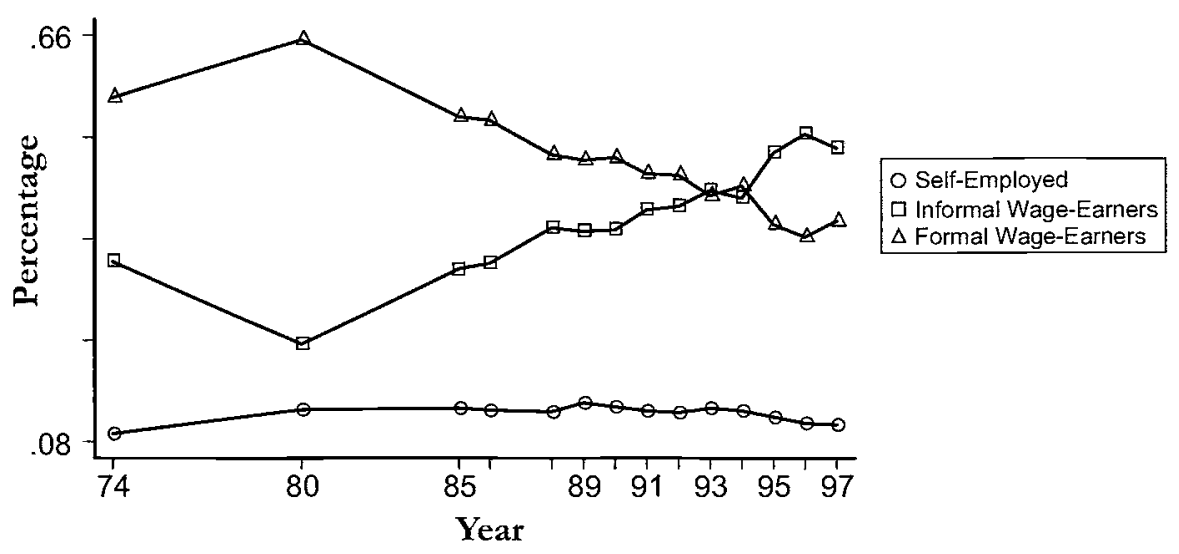

Fig. 6.3 Labor force composition-Gran Buenos Aires, 1974-1997

Source: IERAL database.

\subsubsection{Informality}

A traditional view regards informality as the disadvantaged workers in a dual labor market who are segmented by rules or legal rigidities that introduce high costs in the formal sector. ${ }^{13}$ Only wage earners declare their social security standing and whether they are protected by labor legislation. As it turns out, the correlation between regulatory coverage and social security is close to one. All wage earners registered in the social security system enjoy that protection. The converse is not necessarily true. We define as informal a wage earner who declares himself or herself as not registered in the social security system.

Figure 6.3 shows the breakdown of employment and its evolution for the largest urban center in Argentina: the Greater Buenos Aires area. The graph illustrates a segmentation of the labor market in three basic components: ${ }^{14}$ self-employment, formal wage earners, and informal wage earners. Previous work shows that self-employment constitutes a desirable alternative in itself to formal employment. ${ }^{15}$ PHS data illustrate that the share of

13. An interesting feature of this segment is that it is hard to establish the most important reason why firms opt to operate there. While regulations may be suffocating, the opportunities for tax evasion are also important. Indeed, if the firm holds informal labor contracts, it cannot contribute to social security, but then it must have a source of unreported revenue to pay those wages. This revenue could stem from tax evasion in the goods market. The decision to operate informally may be associated with a complex set of opportunities.

14. The idea of segmentation is used loosely here. We do not mean two completely separate markets but rather two segments of a market that present different prices and somewhat different properties. Because of the nature of many choices in the labor markets (i.e., large fixed costs and/or irreversibility of some decisions), often the pattern of response is different according to whether we are considering wage earners or self-employed people. What we imply by segmentation in such a case is that the rate of transformation between them is limited.

15. The same evidence is available for Mexico. See Maloney $(1997,1998)$ for details. 
self-employed workers remains relatively constant. On the other hand, there is a significant upward trend over the last two decades in the share of informal wage earners.

\subsection{The Effects of Labor Market Regulations: Evidence from Household Microdata}

Job security provisions are, in general, regulatory measures enacted as social protection to mitigate the risk of unemployment among workers by forcing firms to provide subsidies during downturns. The main mechanism is large severance payments that prevent workers from being laid off during downturns. In Argentina it also implies lengthy and expensive procedures that inhibit layoffs by driving up firing costs. It is sometimes argued that the macroeconomic adjustment is further shifted toward the informal sector. Hence, many perceive job security provisions as inequitable for unprotected workers (Riveros and Paredes 1990; Rosenweig 1988). ${ }^{16}$

Those who support regulations in the job market claim that they are commendable to the extent that their objective is the protection of workers against unsafe work practices and unjustified dismissals. They also state that regulations protect the weakest members of society, that they help to redistribute income, and that they stabilize earnings for those people subject to greater risks.

Job security is one form of nonwage compensation. Besides inducing greater immobility, job security increases labor costs to the firm. The increase in labor costs depends on how workers value job security and, specifically, whether it is a substitute for or a complement to wage compensation.

Who benefits from these types of regulations? Do they cost something, at least in terms of forgone earnings? Could we predict which individuals are the most likely to profit from deregulation? These questions have no simple answer but deserve serious consideration before any action is taken to alter the current regulatory standing.

\subsubsection{Who "Benefits" from Regulations?}

The probability of holding a job that is covered by regulations varies across individuals. We analyze a pooled sample of wage earners from the Buenos Aires metropolitan area for the 1975-1997 period. We divide the sample between males and females. The model we estimate is a simple probit equation in which the dependent variable is a dummy distinguishing workers that can claim severance payments in case of dismissal (see table 6A.1 for description of the variables). The correlates included follow.

16. In studies that deal with segmented labor markets, an increase in job security leads to greater labor spillover to informal activities, causing a decline in labor earnings and a higher rate of quasi-voluntary unemployment. 
Educational level: Higher educational level implies higher productivity and should increase the probability of being in the formal sector. Lowereducational-level workers could be pushed to the informal sector because their low productivity may not be enough to counter the added costs of minimum wage laws and other mandatory costs.

Experience: As with any Mincer equation, experience increases general human capital and, hence, productivity.

Tenure on the job: Longer tenure must reflect a better match and greater job-specific human capital. If a firm could choose the type of jobs for which it offered job security, it would provide it to workers that have accumulated a high level of firm-specific human capital. Workers would in turn pay back in the form of higher productivity.

Branch of activity: This consists of a purely empirical set of correlates to account for sector-specific differences in the enforcement capabilities of control agencies, the degree of monopsony power, unionization, and instability of activities.

The size of the company: These characteristics are similar to those of the previous correlate.

Regulatory status of another family member: It is quite possible that workers become increasingly prone to accept job offers without regulatory coverage when a household has diversified risks - in particular, when the spouse or another family member enjoys regulatory coverage. Moreover, the regulatory framework favors precarious insertion for the socalled secondary workers. There is no incentive to register since health and other benefits will not recognize more than one contribution per household.

Marital status: This variable is introduced in the female regression, bearing in mind the gender-biased features of the legislation. We should anticipate a negative sign.

Children under 6: These characteristics are similar to those of the previous correlate.

Table 6.3 reports the results for females and males of the derivatives of a probit model where the dependent variable is the possibility of claiming severance payment compensation if the worker is laid off. ${ }^{17}$

The results indicate that regulations are increasingly prevalent the higher the human capital of the individual. The chances that regulations are present grow with the educational level. Males show, however, that for those with a college education the probability decreases a bit. Those with a university-level education select themselves out of wage-earning jobs and into self-employment to avoid the impact of high taxation. ${ }^{18}$

17. Raw results of probit regressions are reported in table 6A.2.

18. Women, because of their specialization (teaching, nursing, medicine), have a higher probability of being covered than their male counterparts. The reason is that their employer is the government. 
Table 6.3

Probit Estimation: Jobs with Severance Payment Rights (Gran Buenos Aires 1975-1997, wage earners subsample)

\begin{tabular}{|c|c|c|c|c|c|c|}
\hline \multirow[b]{2}{*}{ Variable } & \multicolumn{3}{|c|}{ Women } & \multicolumn{3}{|c|}{ Men } \\
\hline & $\mathrm{dF} / \mathrm{dx}$ & $Z$ & $X$-bar & $\mathrm{dF} / \mathrm{dx}$ & $Z$ & $X$-bar \\
\hline Primary & 0.0466 & 2.14 & 0.3911 & -0.008 & -0.07 & 0.5542 \\
\hline High school & 0.2134 & 9.24 & 0.3572 & 0.0979 & 7.73 & 0.2571 \\
\hline College & 0.2565 & 10.59 & 0.1720 & 0.0773 & 4.43 & 0.0849 \\
\hline Experience & 0.0207 & 11.82 & 20.1224 & 0.0164 & 13.48 & 22.3182 \\
\hline Experience $^{* *} 2$ & -0.0003 & -8.75 & 577.0800 & -0.003 & -11.85 & 670.0120 \\
\hline Tenure & 0.0016 & 3.58 & 6.8277 & 0.0025 & 7.07 & 7.9136 \\
\hline \multicolumn{7}{|l|}{ Construction/House } \\
\hline help & -0.4622 & -20.98 & 0.1645 & -0.2952 & -18.93 & 0.0679 \\
\hline Manufacturing & 0.2169 & 2.15 & 0.0035 & 0.1213 & 3.44 & 0.0134 \\
\hline Retail & 0.0679 & 4.16 & 0.1399 & -0.0436 & -4.32 & 0.1607 \\
\hline Transport & 0.1367 & 4.28 & 0.0277 & -0.0680 & -5.89 & 0.1232 \\
\hline Finance & 0.1299 & 6.86 & 0.1017 & 0.0156 & 1.12 & 0.0897 \\
\hline \multicolumn{7}{|l|}{ Private and Social } \\
\hline Services & 0.1732 & 11.25 & 0.5452 & -0.0057 & -0.58 & 0.2184 \\
\hline Size $<25$ & 0.1755 & 13.54 & 0.2025 & 0.1251 & 16.59 & 0.2362 \\
\hline Size $<100$ & 0.3035 & 21.91 & 0.1781 & 0.2284 & 28.37 & 0.1734 \\
\hline Largest & 0.3052 & 21.26 & 0.1827 & 0.2730 & 33.9 & 0.2332 \\
\hline Family_reg & 0.4455 & 39.67 & 0.3276 & 0.3280 & 41.86 & 0.2672 \\
\hline Ptime & -0.2022 & -16.55 & 0.3532 & -0.1992 & -17.31 & 0.1160 \\
\hline Household Head & 0.0082 & 0.49 & 0.1787 & 0.1422 & 14.8 & 0.6723 \\
\hline Child $<6$ & -0.0054 & -0.5 & 0.1948 & & & \\
\hline Married & -0.0504 & -3.58 & 0.4727 & & & \\
\hline No. of observations & & 13,202 & & & 21,618 & \\
\hline
\end{tabular}

Source: IERAL database.

Notes: $\mathrm{dF} / \mathrm{dx}$ is for discrete change of dummy variable from 0 to $1 . z$ is the test of the underlying coefficient being 0 . See table 6A.1 for description of the variables.

As with most Mincer equations, experience shows the normal concavity. Here it increases the probability of having regulatory coverage. Tenure also shows a positive coefficient that is significantly different from zero.

Family status is also important. Mothers with young children tend to be less protected. Legislation intends to provide coverage for women (maternity leave, special leaves), yet it ends up with a strong market outcome biased against them.

We also find that if another family member happens to enjoy the coverage of regulations, it is more likely that the worker in question has a regulated match. A plausible explanation is that couples are formed with individuals of equivalent condition.

Part-time activities are less protected. The regulatory framework does not favor registration for part-time contracts. Moreover, there are no incentives for it to do so. Contributions to social security (the biggest component of nonwage labor cost) were calculated, up until late 1996, as if the 
worker was employed on a full-time basis. Growth in part-time employment plays an important role in the expansion of nonregistered employment.

Finally, we find that larger firms are more likely to offer regulated jobs.

To summarize, the probit analysis confirms that the regulations tend to segment the market and provide protection to those workers with greater human capital. In other words, the regulatory structure is regressive, and whatever protection it might provide does not appear to benefit those people who are objectively worse off. At the same time, the results show the natural response one would anticipate from rational private decision making. Sectors more exposed to supervision and control (namely, larger firms) are more compliant with regulations.

\subsubsection{Effects on Earnings}

The previous section established that labor market regulations unequivocally affect labor market outcomes in nonrandom ways. It is clear that some groups of workers have a greater chance of having jobs that are under legally enforced regulations. What we have not established, though, is whether workers and firms with those jobs sacrifice something. That is, could it be that a regulated job pays less than a nonregulated one?

One should expect employment protection practices to affect both sides of the labor market: workers and employers. Costs to employers depend not only on the wages paid and the benefit package included but also on labor productivity. Employers should be indifferent to the composition of the total compensation between money wages and benefits.

Employees have preferences between wages and benefits. A crucial parameter when analyzing the size and composition of employer-provided benefits is the wage workers are willing to forgo to obtain benefits. The market value of these trade-offs between wages and fringe benefits is an old research question. This is a difficult empirical issue that, in the literature, does not appear to be resolved. The theoretically predicted negative tradeoff has been difficult to uncover. ${ }^{19}$

In this section we present some estimates of a hedonic wage function. We expect a negative relationship between wages and benefits if productivity is effectively held constant. The problem, of course, is to hold productivity constant in practice. If there are unobserved factors affecting productivity, the negative trade-off is no longer true, since benefits may be related to the unobserved productivity factors.

\section{Econometric Problems}

The worker's decision to accept a job depends on his or her subjective evaluation of the characteristics of the package. In equilibrium, this inter-

19. For a discussion see Smith and Ehrenberg (1983), Leibowitz (1983), and Oi (1983). 
action of workers and employers should yield a locus of job matches that trace out the rate at which the market trades off wages and benefits. In our empirical formulation, we use an extended Mincerian framework.

The regression model we estimate is

$$
\text { Ln } Y_{i, t}=\alpha_{t}+\beta_{t} \mathbf{X}_{i, t}+\theta \text { Regs }+\mu_{i, t},
$$

where $\operatorname{Ln} Y_{i, t}$ is the natural log of monthly individual ( $i$ ) earnings at time $t$. $\mathbf{X}_{i, t}$ is a vector of individual and firm characteristics that encompasses variables such as education, experience, firm size, sector of employment, and so on. Regulations (Regs) reports the legally enforced fringe benefits that characterize the match. The theoretical arguments suggested $\theta$ should be negative. ${ }^{20}$

There are several econometric problems that must be handled. The first one is the typical Heckman sample selection bias: We observe wages only for those employed, not for those that decided not to join the labor force. The result is that the conditional mean for the subsample exceeds the mean for the whole distribution. In this situation a straightforward ordinary least squares (OLS) estimate, not corrected for selectivity bias, would be inconsistent. Our estimation strategy takes this problem into consideration and implements a multilayered decision process.

An important issue in Mincer-type equations is that of unobserved heterogeneity. This comes from the fact that people differ in their ability and capacity to acquire human capital. This misspecification error typically results in inconsistent estimates of parameters. To somewhat mitigate this problem we will condition on tenure on the job. Hopefully, an individual with longer tenure is one who evidences greater abilities, at least in regard to his current position. ${ }^{21}$

20. To empirically prove the rather simple theory, we need data that do not normally exist in standard household surveys. In the case of Argentina the PHS is the only source. Workers report whether they get regulatory coverage. Unfortunately some fringe benefits can only be found in firm-level data sets. High-ability workers (highly motivated, dependable, aggressive) oftentimes receive higher wages and higher fringe benefits. These benefits, which are not proportional to wages, are very difficult to measure.

21. An additional problem springs out of measurement error. It is very likely that those workers that are not covered by regulations underreport their true earnings. If this source of measurement error was present we could get reverse signs in our estimated coefficients on regulations. Now, regulatory benefits could misleadingly turn out greater reported earnings, even though true returns are lower. One could interpret the coefficient on pensions as controlling for this bias and focus the analysis on the coefficients for the other variables. The problem, however, remains in that pensions and the other regulations are highly correlated. Furthermore, regulations could be a last recourse to remain competitive. The wages inefficient firms pay are lower than those of the high-productivity, law-abiding firms. The observed "black" matches could then report lower wages. To introduce some controls for firm efficiency we use the only two pieces of information in the household survey relating to firms: firm size and sector. Of course, many other sources of unobserved productivity differences remain.

Since our estimates are conducted on an artificial panel (stacked cross sections), another serious problem threatens the reliability of the estimates. If the economy has been subject to large structural shocks, as indeed it has, then the returns to human capital or the wage bar- 


\section{Econometric Specification}

The regression model we estimate follows, to a great extent, Heckman's (1979) suggestions. We further take into account the difference between the decision to participate in a job search and that of accepting a job offer. This difference takes particular importance in an environment with high unemployment, such as that observed in the 1990s. Formally, we estimate the likelihood of the individual's reporting income as arising from a bivariate probit considering the individual's decision to join the labor force as well as his or her probability of finding a job.

\section{The Model}

To estimate the rates of return of the different educational levels, a linear version of equation (1) is estimated:

$$
\text { Ln } Y^{*}=\alpha+\beta^{\prime} \mathbf{X}+\theta \text { Regs }+\mu,
$$

where $\mathbf{X}$ is the matrix of independent variables affecting the individual's income level and $\boldsymbol{\mu}$ is the vector of disturbances. The coefficients of education in equation (2) are the average returns to education.

This equation, if estimated by OLS - ignoring the two sources of selectivity bias - can lead to biased parameters. To deal with that problem Heckman (1979) proposed estimating a model of two simultaneous equations, with the endogenous variables being the income and the unobservable reservation wage. In a context of high unemployment, the probability of finding a job and reporting income need not be random or identical to the decision to participate. For this reason, a second-stage Heckman correction was introduced. Details of the model can be found in Tunalli (1982).

The likelihood of the individual's reporting income is estimated from a bivariate probit considering both the individual's decision to join the labor force and his likelihood of getting a job.

Thus, it is assumed that

$$
I_{1 i}^{*}=\delta^{\prime} Z_{i}+\mu_{1 i}
$$

and

$$
I_{2 i}^{*}=\eta^{\prime} W_{i}+\mu_{2 i},
$$

where $Z_{i}$ and $W_{i}$ are independent variables and $I_{1 i}^{*}$ and $I_{2 i}^{*}$ are nonobservable variables associated with an individual's decision to participate and

\footnotetext{
gaining conditions are likely to have changed drastically over time. We introduced a year fixed effect to absorb some of those changes. Pessino (1995) argues that these changes have considerably affected outcomes in the labor market. Garcia (1996) has shown that the Argentine skill premium has moved remarkably over the last few years. He finds that large changes in relative prices (associated to trade reform and deregulation) and technological change explain the large demand shifts necessary to explain the skill premium movements.
} 
Table 6.4

Two-Step Selectivity Bias Process: Individual

\begin{tabular}{llclc}
\hline Decision Process & Labor Force Status & Decision Process & Job Status & Income \\
\hline$I_{1}$ & 0 Nonparticipant & & & Unobserved \\
& 1 Participant & $I_{2}$ & $\begin{array}{l}\text { 0 Unemployed } \\
1 \text { Employed }\end{array}$ & $\begin{array}{l}\text { Unobserved } \\
\text { Observed }\end{array}$ \\
\hline
\end{tabular}

Source: IREAL database.

his success in obtaining employment, respectively. What we observe are those individuals that participate and those that obtained employment.

To summarize, the two-step decision process appears in table 6.4. The equations to be estimated are

$$
\begin{aligned}
I_{1 i, t}^{*} & =\delta^{\prime} Z_{i t}+\mu_{1 i} \\
I_{2 i, t}^{*} & =\eta^{\prime} W_{i t}+\mu_{2 i} \\
\operatorname{Ln} Y_{i t^{*}} & =\beta_{i t^{\prime}} X_{i t}+\theta \text { Regs }+\mu_{3 i} \\
\operatorname{Corr}\left(\mu_{1 i}, \mu_{3 i}\right) & =\rho_{13} \\
\operatorname{Corr}\left(\mu_{2 i}, \mu_{3 i}\right) & =\rho_{23} \\
\operatorname{Corr}\left(\mu_{1 i}, \mu_{2 i}\right) & =\rho_{12}
\end{aligned}
$$

Following Heckman's two-step procedure, we estimate equation

$$
\text { Ln } Y_{i t}^{*}=\beta_{i t}^{\prime} X_{i, t}+\theta \text { Regs }+\gamma_{1} \lambda_{1 i}+\gamma_{2} \lambda_{2 i}+v_{1 i},
$$

where $\lambda_{1} y \lambda_{2}$ are the well-known inverse Mill's ratios

$$
\begin{aligned}
& \lambda_{1}=f\left(\rho_{12}, \delta^{\prime} Z_{i t}, \eta^{\prime} W_{i t}\right) \text { and } \gamma_{1}=\rho_{13} \sigma_{3}, \\
& \lambda_{2}=f\left(\rho_{12}, \eta^{\prime} W_{i t}, \delta^{\prime} Z_{i t}\right) \text { and } \gamma_{2}=\rho_{23} \sigma_{3} .
\end{aligned}
$$

\section{The Data}

Again, we use pooled PHS data for 1975-1997. Workers report their regulatory status there. The questions are quite specific and focus mainly on legally enforced benefits with details for each of them: severance payments, paid holidays, sick leave, social security, and so on. The possible combinations are sixty-four. However, coverage is highly correlated: Workers who are registered in the social security system typically have the right to severance payments as well as the rest of legal benefits. Otherwise they don't have any benefits. For this reason, we define the Regs variable as $1 / 0$. Voluntary fringe benefits provided by employers are not reported to the PHS. ${ }^{22}$ We included the following variables. 
$X$ : Human capital (educational level, Mincerian experience) + current job tenure

Job status: category, occupation (self-employed, wage earner), firm size, branch of activity

Regs: 1 if the person is covered by labor legislation, 0 otherwise

$Z$ : including marital status, head of household, number of children, children under six years ( 0 or 1$)$.

$W$ : including $Z$ plus job status

Table 6.5 reports the results for females and males separately. We chose to report here the estimates for two-step and OLS regressions..$^{23}$ We introduced year fixed effects.

As can be seen in the tables, the estimates show an economically and statistically significant effect of regulations on earnings. Males appear to sacrifice about 8 percent of their earnings when regulations are present. $\mathrm{Fe}-$ males, on the other hand, sacrifice less, though still a significant amount: 2.8 percent of their earnings. It is intuitive that females present lower coefficients. Since the reduction in earnings will come out of the equilibrium match, and since both the demand and the supply sides are likely to shift down with regulations, one would anticipate that the movement would be smaller as the supply side becomes more elastic. There is considerable evidence that the female labor supply is more elastic than that for men.

Results in table 6.5 show estimated returns to schooling and experience, as well as those to tenure, to be rather strong and consistent with the literature. The size of the corporation where the individual works is also quite important. Large corporations appear to be more productive and accordingly pay higher wages (conditional on regulatory benefits).

In summary, our results indicate that regulations do have an important impact on earnings. While we cannot say that they are welfare reducing, it is quite obvious that a job with regulatory coverage does not come for free. One must sacrifice earnings in order to have access to this coverage. At this point it is very important to emphasize that we have estimated reduced forms. Hence, no inference on the elasticity of labor demand or on the marginal rate of substitution in welfare can be made. Yet the result is quite illuminating, particularly when paired with those of the previous subsection.

Regulations are not distributed fairly. They tend to benefit those with higher earning potential and do segment the market. Those that do get some coverage, however, must sacrifice a portion of their earnings. Still, as we just mentioned, we have not connected the potential impact of regulations to labor demand. For this reason, it is difficult to make any structural inferences as to how the market would clear once these regulations are 


\begin{tabular}{|c|c|c|c|c|}
\hline \multirow[b]{2}{*}{ Variable } & \multicolumn{2}{|c|}{ Females } & \multicolumn{2}{|c|}{ Males } \\
\hline & 2 Step & OLS & 2 Step & OLS \\
\hline Lamp & $\begin{array}{c}-.2343 \\
(-6.558)^{* * *}\end{array}$ & & $\begin{array}{c}-.1815 \\
(-3.378)^{* * *}\end{array}$ & \\
\hline Lame & $\begin{array}{r}.9478 \\
(1.612)\end{array}$ & & $\begin{array}{c}-.5816 \\
(-4.421)^{* * *}\end{array}$ & \\
\hline Primary & $\begin{array}{c}.1199 \\
(5.191)^{* * *}\end{array}$ & $\begin{array}{c}.3343 \\
(8.184)^{* * *}\end{array}$ & $\begin{array}{c}.2210 \\
(14.131)^{* * *}\end{array}$ & $\begin{array}{c}.2475 \\
(18.039)^{* * *}\end{array}$ \\
\hline High school & $\begin{array}{c}.5649 \\
(21.62)^{* * *}\end{array}$ & $\begin{array}{c}.886 \\
(18.349)^{* * *}\end{array}$ & $\begin{array}{c}.6799 \\
(31.033)^{* * *}\end{array}$ & $\begin{array}{c}.7589 \\
(47.85)^{* * *}\end{array}$ \\
\hline College & $\begin{array}{c}1.0448 \\
(12.315)^{* * *}\end{array}$ & $\begin{array}{c}1.3646 \\
(24.691)^{* * *}\end{array}$ & $\begin{array}{c}1.264 \\
(44.595)^{* * *}\end{array}$ & $\begin{array}{c}1.3857 \\
(69.289)^{* * *}\end{array}$ \\
\hline Experience & $\begin{array}{c}.0256 \\
(7.216)^{* * *}\end{array}$ & $\begin{array}{c}.0371 \\
(11.856)^{* * *}\end{array}$ & $\begin{array}{c}.013 \\
(4.448)^{* * *}\end{array}$ & $\begin{array}{c}.0312 \\
(24.885)^{* * *}\end{array}$ \\
\hline Experience**2 & $\begin{array}{c}-.003 \\
(-4.515)^{* * *}\end{array}$ & $\begin{array}{c}-.005 \\
(-8.293)^{* * *}\end{array}$ & $\begin{array}{c}-.008 \\
(-1.463)\end{array}$ & $\begin{array}{c}-.004 \\
(-17.420)^{* * *}\end{array}$ \\
\hline Tenure & $\begin{array}{c}.0064 \\
(7.956)^{* * *}\end{array}$ & $\begin{array}{c}.0056 \\
(4.161)^{* * *}\end{array}$ & $\begin{array}{c}.0072 \\
(16.579)^{* * *}\end{array}$ & $\begin{array}{c}.0071 \\
(16.351)^{* * *}\end{array}$ \\
\hline Manufacturing & $\begin{array}{l}-.1085 \\
(5.100)^{* * *}\end{array}$ & $\begin{array}{l}.0368 \\
(.912)\end{array}$ & $\begin{array}{c}.0458 \\
(3.212)^{* * *}\end{array}$ & $\begin{array}{c}.0479 \\
(3.352)^{* * *}\end{array}$ \\
\hline Public Services & $\begin{array}{r}.1212 \\
(1.477)\end{array}$ & $\begin{array}{l}.1299 \\
(.617)\end{array}$ & $\begin{array}{c}.1402 \\
(3.241)^{* * *}\end{array}$ & $\begin{array}{c}.1428 \\
(3.294)^{* * *}\end{array}$ \\
\hline Construction/Maids & $\begin{array}{c}.1587 \\
(6.401)^{* * *}\end{array}$ & $\begin{array}{c}.3129 \\
(6.797)^{* * *}\end{array}$ & $\begin{array}{l}.0088 \\
(.503)\end{array}$ & $\begin{array}{l}.0116 \\
(.664)\end{array}$ \\
\hline Retail & $\begin{array}{l}-.1800 \\
(-.7329)\end{array}$ & $\begin{array}{l}-.0401 \\
(-.922)\end{array}$ & $\begin{array}{l}-.003 \\
(-.198)\end{array}$ & $\begin{array}{l}-.0033 \\
(-.213)\end{array}$ \\
\hline Private Services & $\begin{array}{c}.1307 \\
(5.937)^{* * *}\end{array}$ & $\begin{array}{c}.2563 \\
(6.113)^{* * *}\end{array}$ & $\begin{array}{c}.0632 \\
(4.367)^{* * *}\end{array}$ & $\begin{array}{c}.0648 \\
(4.47)^{* * *}\end{array}$ \\
\hline Public Administration & $\begin{array}{l}.0119 \\
(.583)\end{array}$ & $\begin{array}{c}.1052 \\
(2.621)^{* * *}\end{array}$ & $\begin{array}{l}-.0094 \\
(-.489)\end{array}$ & $\begin{array}{l}-.0105 \\
(-.542)\end{array}$ \\
\hline Social Services & $\begin{array}{c}.1666 \\
(3.226)^{* * *}\end{array}$ & $\begin{array}{c}.3116 \\
(3.963)^{* * *}\end{array}$ & $\begin{array}{l}.0089 \\
(.336)\end{array}$ & $\begin{array}{l}.0061 \\
(.23)\end{array}$ \\
\hline Size5 & $\begin{array}{l}.0063 \\
(.238)\end{array}$ & $\begin{array}{c}.2158 \\
(4.335)^{* * *}\end{array}$ & $\begin{array}{c}.008 \\
(.049)\end{array}$ & $\begin{array}{l}.0018 \\
(.112)\end{array}$ \\
\hline Size $<25$ & $\begin{array}{c}.0682 \\
(2.685)^{* * *}\end{array}$ & $\begin{array}{c}.2875 \\
(5.850)^{* * *}\end{array}$ & $\begin{array}{c}.0785 \\
(4.801)^{* * *}\end{array}$ & $\begin{array}{c}.0811 \\
(4.954)^{* * *}\end{array}$ \\
\hline Size $<100$ & $\begin{array}{c}0.0984 \\
(3.804)^{* * *}\end{array}$ & $\begin{array}{c}.3072 \\
(6.037)^{* * *}\end{array}$ & $\begin{array}{c}.1346 \\
(7.697)^{* * *}\end{array}$ & $\begin{array}{c}.1384 \\
(7.900)^{* * *}\end{array}$ \\
\hline Largest & $\begin{array}{c}.1654 \\
(2.89)^{* * * *}\end{array}$ & $\begin{array}{c}.3953 \\
(7.739)^{* * * *}\end{array}$ & $\begin{array}{c}.2222 \\
(13.236)^{* * *}\end{array}$ & $\begin{array}{c}.2278 \\
(13.553)^{* * *}\end{array}$ \\
\hline Self & $\begin{array}{c}.0762 \\
(3.996)^{* * *}\end{array}$ & $\begin{array}{c}.0682 \\
(2.047)^{* * *}\end{array}$ & $\begin{array}{c}.0474 \\
(3.605)^{* * *}\end{array}$ & $\begin{array}{c}.0538 \\
(4.091)^{* * *}\end{array}$ \\
\hline Regs & $\begin{array}{r}-.0284 \\
(-1.687)\end{array}$ & $\begin{array}{l}-.0039 \\
(-.123)\end{array}$ & $\begin{array}{l}-0.0826 \\
(-7.363)^{* * *}\end{array}$ & $\begin{array}{l}-.0757 \\
(-.6744)^{* * *}\end{array}$ \\
\hline Constant & $\begin{array}{c}1.7757 \\
(10.561)^{* * *}\end{array}$ & $\begin{array}{c}1.0312 \\
(13.262)^{* * *}\end{array}$ & $\begin{array}{c}10.7873 \\
(221.212)^{* * *}\end{array}$ & $\begin{array}{c}10.435 \\
(345.769)^{* * *}\end{array}$ \\
\hline Adjusted $R^{2}$ & & & & 612 \\
\hline
\end{tabular}

Source: IERAL database.

Note: See table 6A.1 for description of the variables. Absolute value of $t$-statistics in parentheses.

***Significant at the 1 percent level. 
eliminated. In the next section, we turn to a different exercise and estimate labor demand for a large number of manufacturing firms in Argentina.

\subsection{Labor Demand Estimation}

We argued previously that most of the regulatory impact would operate through the demand for labor. Theoretical arguments suggest that regulations in the form of taxes will have a negative impact on employment and/ or wages. Contributions to social security are typically thought to affect negatively the demand for labor as well, since the effects through labor supply are probably modest (in countries like Argentina, where workers do not perceive the contributions as deferred or indirect wages, this effect is likely to be very small). Theory, however, provides relatively less guidance over the effects of severance payments on employment. While they are likely to change the ease with which payroll is managed, it is not clear that they reduce the aggregate demand for labor. It appears crucial to have an empirical estimate of how firms respond, in their labor demand decisions, to the presence of regulations.

Hamermesh (1986), summarizing the literature, provides empirical estimates of the employment/labor cost elasticities for various industrial countries. He found the parameter to be low in the sample (.1 to .5), suggesting that policies that increase the fixed cost of employment may reduce the employment-hours ratio only slightly. However, these elasticities could be biased downward as they may reflect the effect of prevailing job security, since these regulations would have induced a substitution away from labor. Less controversial than the effect of job security on the adjustment process is its effect on employment. An increase in job security increases the cost of hiring due to changes in expected future severance payments and the cost of forgone output due to potential mismatches. In the context of shocks to output, firms must strike a balance between hiring more workers and waiting a few periods to forgo the high potential future severance payment.

This section presents the results of estimating a homogeneous labor demand equation with a previously unexploited balanced panel of Argentine manufacturing firms. Our empirical analysis considers the adjustment of employment and hours over the 1990-1996 period.

One of the rich features of the data set is the availability of employment and hours worked. Since some of the effects of stiffening regulations are likely to be a more intense use of hours, we are likely to uncover features here that papers with more aggregate data sources cannot. Of particular interest is the adjustment in the intensive margin (hours) that can follow an increase in the perceived cost of severance. For instance, increases in the demand for goods accompanied by higher severance costs are likely to lead to a reasonably constant level of employment but a more intense use of overtime.

Panel data estimations such as those pursued here present some draw- 
backs. To begin with, the relatively short period of time covered restricts the variability of regulations. In particular, as mentioned before, there were relatively few changes in the period under consideration, and those that took place happened toward the end of the sample. In any event, as we will see, the effects of regulations come out strongly and highly significant. A second limitation is that the period was one of extraordinary change in a number of dimensions: a large number of firm deaths and births (unfortunately not adequately captured by the sampling technique used to create the panel) and, most remarkably, a period of such strenuous firm reengineering that it casts some concerns over the values of long-run elasticities. On the other hand, the high variance in some of the forcing variables allows a more efficient estimation of the parameters.

\subsubsection{The Model}

Our empirical approach models labor demand through a fairly general setting. We characterize employment choices as the dynamic interaction of employment and hours adjusting to fluctuations in output, factor prices, and regulations. While the system that will be estimated is unconstrained, the specifications for the demand system correspond to a substantial number of production structures. ${ }^{24}$ The system is summarized by the following two equations:

$$
\begin{aligned}
\operatorname{Ln} E_{t}= & \alpha_{1}+\alpha_{2} \operatorname{Ln} E_{t-k}+\alpha_{3} \operatorname{Ln} \operatorname{Regs}+\alpha_{4} \operatorname{Ln} H_{t-k} \\
& +\beta \operatorname{Ln} \operatorname{Sat}+\gamma \operatorname{Lin} P_{t}+\varepsilon_{1 t} \\
\text { Ln } H_{t}= & \alpha_{1}+\alpha_{2} \operatorname{Ln} H_{t-k}+\alpha_{3} \operatorname{Ln} \operatorname{Regs}+\alpha_{4} \operatorname{Ln} E_{t-k} \\
& +\beta \operatorname{Ln} \text { Sat }+\gamma \operatorname{Lin} P_{t}+\varepsilon_{2 t},
\end{aligned}
$$

where $E_{t}$ is employment, $H_{t}$ are production hours, $P_{t}$ is industrial production. Regs measures the cost equivalence of regulations, which presumably affect not just the level of demand but also the dynamics. Finally, Sat captures the product wage.

The model assumes that employers seek to maximize the expected value of current and future profit and that the cost of adjusting labor input is a quadratic function of the size of the adjustment made.

The specification is quite flexible. It is consistent with a number of production structures with smooth substitution between workers and hours, including varying degrees of returns to scale or what is even more likely, the presence of imperfect competition in goods markets. In other words, the model does not restrict the source of curvature of the profit function..$^{25}$

24. The corresponding derivations may be consulted in Varian (1984), MasCollel, Whinston, and Green (1995), Chambers (1988), and Hamermesh (1986, 1993).

25 . For instance, the model is consistent with a setting where firms are imperfectly competitive and face constant marginal costs as well as with one where firms face a competitive market with decreasing returns to labor. 
Given this generality, care must be taken to make explicit the maintained hypotheses if the coefficients are to be identified as technology parameters.

It is important to consider the theoretical model on which the specification is based so as to understand the true significance of the parameters. If the production process is assumed to have the features of a Cobb-Douglas production function, labor costs and production parameters are interpreted as labor and return-to-scale parameters, respectively. If, on the other hand, it is assumed that a constant elasticity of substitution (CES) production function explains the model better, the corresponding coefficients represent the capital-labor substitution elasticity and the scale parameter, respectively. In any case, in the estimations presented herein, no restrictions on production function or underlying cost structure will be imposed.

\subsubsection{Econometric Specification}

The system represented by equations (11) and (12) presents a number of econometric problems that must be addressed.

First, the model, being based on a panel, will be estimated with fixed effects to control for firm idiosyncratic factors. We will also introduce a quarter dummy to correct for any seasonality in the unadjusted data. ${ }^{26}$

Under most reasonable assumptions (local returns to scale, imperfect competition, bargaining structures, and so on) firm output and shocks to the demand decision are likely to be correlated. The same can be said about real wage determination. This, of course, requires the estimation through instrumental variables. At a micro level, the choice of instruments becomes a bit easier than in aggregate models. However, finding firm-specific instruments proved to be very difficult as the data set did not include truly exogenous variables. For this reason, we used a number of aggregate variables and estimated different correlations for each firm. ${ }^{27}$ The instruments used are aggregate GDP, the specific branch openness indicator (export plus imports over output), aggregate unemployment rate, price of capital equipment index, log of ratio of wholesale prices to consumer prices, and lagged values of all variables. We report results from OLS and instrumental variables (IV) estimations. Following Bentolila and Saint-Paul (1992), we did not expect labor demand to be stable over the firm's cycle. ${ }^{28}$ To partially account for this we defined a dummy variable to capture recessions and expansions when instrumenting. We defined both states as occurring when the real output $(\log )$ growth reached a threshold arbitrarily imposed (see table 6A.5 for details).

26. Theory indicates that when estimating labor demand conditioned on production (not value added) we should include other factor prices. Nonlabor inputs were unavailable for the estimation.

27. The instruments, while the same for each firm, did vary in that they were not restricted to share the same first-stage coefficients for all firms.

28. Bentolila and Saint-Paul (1992) argue that a lowering in firing cost affects more firing decisions than hiring ones. 
The model specification introduces an unrestricted dynamic adjustment. This is motivated via a cost of adjustment technology that depends in part on the hurdles imposed by regulations. The specification we chose was to introduce up to three lags to capture all seasonal as well as inertial factors. To allow for a richer interaction with hours, we also introduced lagged terms of hours in the employment equation and vice versa. As for adjustment costs, we also introduced as an explanatory variable the price of overtime hours. Presumably, an increase in the number of (relative) overtime hours should induce an increase in the level of employment next period. The fact that overtime hours are being used at all is probably a good indicator of significant adjustment costs..$^{29}$

\subsubsection{The Data}

The data set includes a sample of 1,398 manufacturing private firms. The panel does not provide much information on the type of firms included. For instance, we have no knowledge of whether the employment relations are informal. The panel presents other problems, too. Not all firms systematically answer all questions. Similarly, many firms drop out of the sample, and the replacement criterion is not clear. The panel does not include newly created firms. We report results from estimating a restricted balanced panel and an unbalanced one. The balanced panel drops all those firms that do not answer the relevant questions or that have dropped out of the sample, leaving 200 firms in the data set with all the complete answers for the whole period. Clearly, this decision could create a selectivity bias problem. ${ }^{30}$ The unbalanced panel, on the other hand, clears out those firms that do not answer the relevant questions in all quarters. The number of remaining firms was 549 out of the original 1,398. ${ }^{31}$ Sources and additional details concerning the data are explained in appendix B.

The available data are in index number format. The definition of each variable has its own complexities. We defined employment as the total number of workers within the firm (white and blue collar). Production is measured via physical production as reported by firms. Multiproduct firms aggregate it up according to a set of fixed weights. There is no control for changes in product design. Wages were defined by dividing payroll ex-

29. When estimating the interaction between hours and employment, it is clear that both respond to a correlated set of innovations. In this paper we estimated them separately. A refinement would estimate them jointly, allowing for a free correlation between both residuals.

30. The problem is complex. First, the methodology claims to replace small firms in the sample but not large ones. Second, we cannot distinguish between firms that did not answer because they decided not to do so (perhaps out of taxation fears) and the ones that were closed. Finally, there is no information in the data to allow us to identify firms that are likely to be dropped out of the sample to attempt a solution to the selectivity bias (i.e., we have no way in which to identify if a firm is large or small).

31. We considered the possibility of reweighting the panel, but it proved impossible because in the balanced panel entire branches were lost. Therefore, we did not have any criteria for expanding the sample. 
Table 6.6

Descriptive Statistics of Firms in the Sample: Annual Average

Growth Rate

\begin{tabular}{lrr}
\hline Index & $(1)$ & (2) \\
\hline Employment & -3.0 & -2.7 \\
Hours & 3.2 & 1.1 \\
Total wage & 10.9 & 10.6 \\
Hourly wage & 7.5 & 9.9 \\
Regulation cost & -1.3 & 4.0 \\
Output & 8.0 & 5.7 \\
\hline
\end{tabular}

Source: IERAL database.

Notes: Column (1) is based on extremes values on the series; column (2) is based on the slope of the trend line.

penses by the number of employees. Since we have data on expenses due to overtime hours, we netted them out to compute regular wages. The survey does not include product price information. We estimated the real wage as the ratio of wages to wholesale prices for the sector. For description of the variables see table 6A.5.

Table 6.6 shows some features of the firms in our sample. The table presents average growth rates for a few variables. LnReg is the variable that encompasses labor regulation costs. We included payroll taxes: pensions, family allowances, health care system, and PAMI (see table 6.2 for details). We also introduced a measure of expected severance payments (ESP). We did not include other labor regulations due to the difficulties involved in imputing costs. This was the case with paid holidays, sick leave, and specific collective agreement provisions.

\section{The Index of Regulations Construction}

LnReg is estimated every period for each branch of activity. LnReg has two main components: taxes and ESP. Expected severance payment is calculated as percentage of normal wage through the following formula:

$$
\mathrm{ESP}_{i t}=U_{i t} \cdot F_{i t} \cdot T_{i t} \cdot P_{i t},
$$

where $i$ refers to firm's branch of activity and $t$ refers to time (quarter and year); $U$ is the unemployment rate, $F$ is the percentage of fired people over unemployment; $T$ is average tenure, and $P$ is the probability of having the right to severance (the fraction of formal wage earners over total wage earners). Each period we have as many ESPs as branches of activities aggregated at two digits of the third revision of the Clasificación Industrial International Uniforme (CIIU). Because the PHS is gathered twice a year and we have quarterly data, we use the same figure for every two quarters of the Manufacturing Industrial Survey.

We add the taxes to ESP to obtain the full cost of regulation as a proportion of wages. 




Fig. 6.4 Decomposition of expected severance payment

Source: IERAL database.

$$
\operatorname{Regs}_{i t}=\mathrm{ESP}_{i t}+\text { Taxes }_{i t}
$$

The variable is expressed as an index base $1990=100$ and expressed in logarithm for the regressions. The behavior of the different components of the index is illustrated in figure 6.4.

\subsubsection{Results}

Table 6.7 presents some OLS results. Our first specification treats output as exogenous. Estimates for jobs and hours are reported for the unbalanced and the balanced panel, respectively. We estimated introducing individual firm fixed effects, correcting for serial correlation. The reported $z$-score is heteroskedasticity consistent.

The results show that all variables are statistically significant. A 1 percent increase in real wages decreases the level of employment 0.15 percent while hours go down 0.20 percent. A common pattern in our results and the literature is that hours appear more responsive to changes in costs or scale factors. This is probably the effect of costs of adjustment. Theory indicates that with costly changes in manpower a firm is much more likely to rely on adjustments in hours per worker than on the number of jobs offered. ${ }^{32}$

As we mentioned in the introduction, eyeballing the data leads to the im-

32. It must be remembered, however, that overtime hours are costlier, and thus firms have to take this into account. 
Manufacturing Survey: OLS Results

\begin{tabular}{|c|c|c|c|c|}
\hline & \multicolumn{2}{|c|}{ Unbalanced Panel } & \multicolumn{2}{|c|}{ Balanced Panel } \\
\hline & $\begin{array}{l}\text { Employment } \\
\text { (1) }\end{array}$ & $\begin{array}{l}\text { Hours per Worker } \\
\text { (2) }\end{array}$ & $\begin{array}{c}\text { Employment } \\
\text { (3) }\end{array}$ & $\begin{array}{l}\text { Hours per Worker } \\
\text { (4) }\end{array}$ \\
\hline Normal Wage & $\begin{array}{l}-0.151 \\
(21.23)^{* * *}\end{array}$ & $\begin{array}{l}-0.197 \\
(41.78)^{* * *}\end{array}$ & $\begin{array}{l}-0.119 \\
(14.40)^{* * *}\end{array}$ & $\begin{array}{l}-0.180 \\
(29.63)^{* * *}\end{array}$ \\
\hline Output & $\begin{array}{c}0.117 \\
(33.22)^{* * *}\end{array}$ & $\begin{array}{c}0.061 \\
(24.22)^{* * *}\end{array}$ & $\begin{array}{c}0.103 \\
(20.01)^{* * *}\end{array}$ & $\begin{array}{c}0.071 \\
(17.08)^{* * *}\end{array}$ \\
\hline Output_1 & $\begin{array}{l}-0.048 \\
(12.50)^{* * *}\end{array}$ & $\begin{array}{l}-0.023 \\
(8.23)^{* * *}\end{array}$ & $\begin{array}{l}-0.049 \\
(8.94)^{* * *}\end{array}$ & $\begin{array}{l}-0.035 \\
(7.95)^{* * *}\end{array}$ \\
\hline Overtime Wage & $\begin{array}{l}0.015 \\
(8.21)^{* * *}\end{array}$ & $\begin{array}{c}0.063 \\
(49.52)^{* * *}\end{array}$ & $\begin{array}{l}0.018 \\
(7.03)^{* * *}\end{array}$ & $\begin{array}{c}0.062 \\
(31.46)^{* * *}\end{array}$ \\
\hline Employment_1 & $\begin{array}{c}0.815 \\
(88.69)^{* * *}\end{array}$ & $\begin{array}{l}-0.059 \\
(9.06)^{* * *}\end{array}$ & $\begin{array}{c}0.878 \\
(64.26)^{* * *}\end{array}$ & $\begin{array}{l}-0.077 \\
(7.13)^{* * *}\end{array}$ \\
\hline Employment_2 & $\begin{array}{l}-0.239 \\
(21.48)^{* * *}\end{array}$ & $\begin{array}{l}0.026 \\
(3.28)^{* * *}\end{array}$ & $\begin{array}{l}-0.277 \\
(15.67)^{* * *}\end{array}$ & $\begin{array}{l}0.051 \\
(3.64)^{* * *}\end{array}$ \\
\hline Employment_3 & $\begin{array}{c}0.275 \\
(31.17)^{* * *}\end{array}$ & $\begin{array}{l}-0.030 \\
(4.72)^{* * *}\end{array}$ & $\begin{array}{c}0.270 \\
(20.41)^{* * *}\end{array}$ & $\begin{array}{l}-0.023 \\
(2.19)^{* *}\end{array}$ \\
\hline Hours per Worker_1 & $\begin{array}{l}0.022 \\
(2.00)^{* *}\end{array}$ & $\begin{array}{c}0.172 \\
(21.57)^{* * *}\end{array}$ & $\begin{array}{l}0.037 \\
(2.42)^{* * *}\end{array}$ & $\begin{array}{c}0.251 \\
(20.37)^{* * *}\end{array}$ \\
\hline Hours per Worker_2 & $\begin{array}{l}0.073 \\
(6.56)^{* * *}\end{array}$ & $\begin{array}{c}0.001 \\
(0.16)\end{array}$ & $\begin{array}{r}0.007 \\
(0.50)\end{array}$ & $\begin{array}{r}0.015 \\
(1.30)\end{array}$ \\
\hline Hours per Worker_3 & $\begin{array}{l}0.042 \\
(4.13)^{* * *}\end{array}$ & $\begin{array}{c}0.014 \\
(1.87)^{* *}\end{array}$ & $\begin{array}{l}0.084 \\
(6.46)^{* * *}\end{array}$ & $\begin{array}{l}0.033 \\
(3.18)^{* * *}\end{array}$ \\
\hline Second quarter & $\begin{array}{l}-0.033 \\
(7.89)^{* * *}\end{array}$ & $\begin{array}{c}0.100 \\
(33.32)^{* * *}\end{array}$ & $\begin{array}{l}-0.040 \\
(8.57)^{* * *}\end{array}$ & $\begin{array}{c}0.100 \\
(25.99)^{* * *}\end{array}$ \\
\hline Third quarter & $\begin{array}{l}-0.032 \\
(7.39)^{* * *}\end{array}$ & $\begin{array}{c}0.099 \\
(31.49)^{* * *}\end{array}$ & $\begin{array}{l}-0.032 \\
(6.44)^{* * *}\end{array}$ & $\begin{array}{c}0.089 \\
(22.32)^{* * *}\end{array}$ \\
\hline Fourth quarter & $\begin{array}{l}-0.018 \\
(4.59)^{* * *}\end{array}$ & $\begin{array}{c}0.085 \\
(29.42)^{* * *}\end{array}$ & $\begin{array}{l}-0.015 \\
(3.29)^{* * *}\end{array}$ & $\begin{array}{c}0.075 \\
(20.59)^{* * *}\end{array}$ \\
\hline Regulation & $\begin{array}{l}-0.013 \\
(2.04)^{* *}\end{array}$ & $\begin{array}{l}0.031 \\
(6.80)^{* * *}\end{array}$ & $\begin{array}{l}-0.009 \\
(1.22)\end{array}$ & $\begin{array}{l}0.028 \\
(4.82)^{* * *}\end{array}$ \\
\hline Constant & $\begin{array}{l}0.441 \\
(5.20)^{* * *}\end{array}$ & $\begin{array}{c}4.322 \\
(70.69)^{* * *}\end{array}$ & $\begin{array}{l}0.277 \\
(2.63)^{* * *}\end{array}$ & $\begin{array}{c}3.689 \\
(42.81)^{* * *}\end{array}$ \\
\hline $\begin{array}{l}\text { Adjusted } R^{2} \\
\text { No. of observations }\end{array}$ & .89 & 11,061 & .86 & 4,997 \\
\hline
\end{tabular}

Source: IERAL database.

Notes: Absolute value of $z$-statistics in parentheses. See table 6A.5 for description of the variables. ***Significant at the 1 percent level.

**Significant at the 5 percent level.

pression that Argentina's job market showed apparent low responsiveness of employment to output. Our OLS estimates show that, in manufacturing, when output grows 1 percent, hours increase 6-7 percent and workers $10-$ 12 percent on impact.

A feature of the results is that output and wage elasticities are higher in 
the unbalanced panel than in the balanced one. Unfortunately, the selection rule to stay in the panel is unclear. Firms could die or simply not answer in some periods. Thus, while the results are suggestive, there is no real basis to conclude that regulations do have an impact in pushing firms into bankruptcy.

The model reported in table 6.7 shows, in both panels, fairly similar results. Employment and hours appear sensitive to wages. Remarkably, the cost of regulations (severance costs and taxes) always affects significantly the demand for workers. The results, however, assumed that physical volume of production as well as wages could be treated as exogenous, ignoring questions of simultaneity in the determination of output, employment, and prices.

When using microdata the simultaneous problems of output determination and employment are typically avoided. The reason is simple: Under perfect competition, demand is given and hence firms only choose how many workers to hire. Unfortunately, in the case at hand, the assumption of competitive markets may be a bit strict — at least for the first few years of the sample, when the economy was quite closed and few firms disputed the local market. Under imperfect competition the decisions to hire workers and sell goods are closely intertwined, and disturbances that affect one will probably affect the other. For this reason we should instrument for movements in final goods demand. ${ }^{33}$

As for wages, firms have a limited say in the wage offer. The institutional setting in Argentina limits that discretion. Centralized bargaining restricts the choices for a firm, and only upward deviations in wages are allowed. Furthermore, the price deflator used to construct the real wage, just as the level of output, is endogenous under imperfect competition. For this reason, in table 6.8 we report instrumental variable estimations assuming both wage costs and output as jointly determined with employment.

The instrumental variable estimation makes little change in the shortrun output elasticities in the employment equations. The elasticity for the hours equation, on the other hand, doubles. Interestingly, it appears that the endogeneity problem was more serious for the hours equation - the margin where most changes would take place when in the presence of adjustment costs. This pattern is present in both tables and is most remarkable in the unbalanced panel estimates.

The responsiveness of employment to changes in wage costs is a bit more of a concern. When we only instrument for output, the elasticity remains stable at a $0.15-0.20$ level (in the unbalanced panel case). However, when we instrument for the potential endogeneity of wages, the cost elasticity

33. Table 6A.6 shows the results of instrumenting the level of output assuming wages to be exogenous. 


\begin{tabular}{|c|c|c|c|c|}
\hline & \multicolumn{2}{|c|}{ Unbalanced Panel } & \multicolumn{2}{|c|}{ Balanced Panel } \\
\hline & $\begin{array}{c}\text { Employment } \\
\text { (1) }\end{array}$ & $\begin{array}{l}\text { Hours per Worker } \\
\text { (2) }\end{array}$ & $\begin{array}{c}\text { Employment } \\
\text { (3) }\end{array}$ & $\begin{array}{c}\text { Hours per Worker } \\
\text { (4) }\end{array}$ \\
\hline Est. Normal Wage & $\begin{array}{l}-0.118 \\
(10.27)^{* * *}\end{array}$ & $\begin{array}{l}-0.022 \\
(2.61)^{* * *}\end{array}$ & $\begin{array}{l}-0.041 \\
(3.09)^{* * *}\end{array}$ & $\begin{array}{l}-0.038 \\
(3.61)^{* * *}\end{array}$ \\
\hline Est. Output & $\begin{array}{l}0.110 \\
(9.72)^{* * *}\end{array}$ & $\begin{array}{c}0.103 \\
(12.11)^{* * *}\end{array}$ & $\begin{array}{l}0.050 \\
(3.68)^{* * *}\end{array}$ & $\begin{array}{c}0.124 \\
(10.75)^{* * *}\end{array}$ \\
\hline Output_1 & $\begin{array}{l}-0.042 \\
(6.61)^{* * *}\end{array}$ & $\begin{array}{l}-0.045 \\
(9.30)^{* * *}\end{array}$ & $\begin{array}{l}-0.030 \\
(3.58)^{* * *}\end{array}$ & $\begin{array}{l}-0.065 \\
(9.04)^{* * *}\end{array}$ \\
\hline Overtime Wage & $\begin{array}{l}0.016 \\
(6.29)^{* * *}\end{array}$ & $\begin{array}{c}0.062 \\
(32.96)^{* * * *}\end{array}$ & $\begin{array}{l}0.022 \\
(6.61)^{* * *}\end{array}$ & $\begin{array}{c}0.055 \\
(20.37)^{* * *}\end{array}$ \\
\hline Employment_1 & $\begin{array}{c}0.825 \\
(76.24)^{* * *}\end{array}$ & $\begin{array}{l}-0.056 \\
(6.94)^{* * *}\end{array}$ & $\begin{array}{c}0.910 \\
(59.58)^{* * *}\end{array}$ & $\begin{array}{l}-0.071 \\
(5.50)^{* * *}\end{array}$ \\
\hline Employment_2 & $\begin{array}{l}-0.260 \\
(19.16)^{* * *}\end{array}$ & $\begin{array}{l}0.042 \\
(4.00)^{* * *}\end{array}$ & $\begin{array}{l}-0.317 \\
(16.03)^{* * *}\end{array}$ & $\begin{array}{l}0.063 \\
(3.64)^{* * *}\end{array}$ \\
\hline Employment_3 & $\begin{array}{c}0.310 \\
(28.22)^{* * * *}\end{array}$ & $\begin{array}{l}-0.051 \\
(6.29)^{* * * *}\end{array}$ & $\begin{array}{c}0.294 \\
(20.14)^{* * * *}\end{array}$ & $\begin{array}{l}-0.032 \\
(2.66)^{* * * *}\end{array}$ \\
\hline Hours per Worker_1 & $\begin{array}{l}0.038 \\
(2.90)^{* * *}\end{array}$ & $\begin{array}{c}0.202 \\
(20.70)^{* * *}\end{array}$ & $\begin{array}{c}0.015 \\
(0.85)\end{array}$ & $\begin{array}{c}0.279 \\
(19.08)^{* * *}\end{array}$ \\
\hline Hours per Worker_2 & $\begin{array}{l}0.076 \\
(5.99)^{* * *}\end{array}$ & $\begin{array}{l}-0.015 \\
(1.51)\end{array}$ & $\begin{array}{r}0.001 \\
(0.05)\end{array}$ & $\begin{array}{r}0.021 \\
(1.47)\end{array}$ \\
\hline Hours per Worker_3 & $\begin{array}{l}0.036 \\
(2.95)^{* * *}\end{array}$ & $\begin{array}{c}0.013 \\
(1.42)\end{array}$ & $\begin{array}{l}0.051 \\
(3.34)^{* * *}\end{array}$ & $\begin{array}{l}0.026 \\
(2.05)^{* *}\end{array}$ \\
\hline Second quarter & $\begin{array}{l}-0.028 \\
(5.97)^{* * *}\end{array}$ & $\begin{array}{c}0.123 \\
(33.08)^{* * * *}\end{array}$ & $\begin{array}{l}-0.033 \\
(6.24)^{* * *}\end{array}$ & $\begin{array}{c}0.112 \\
(24.36)^{* * * *}\end{array}$ \\
\hline Third quarter & $\begin{array}{l}-0.029 \\
(5.74)^{* * *}\end{array}$ & $\begin{array}{c}0.122 \\
(31.44)^{* * *}\end{array}$ & $\begin{array}{l}-0.021 \\
(3.87)^{* * *}\end{array}$ & $\begin{array}{c}0.105 \\
(22.08)^{* * *}\end{array}$ \\
\hline Fourth quarter & $\begin{array}{l}-0.020 \\
(4.11)^{* * *}\end{array}$ & $\begin{array}{c}0.100 \\
(27.50)^{* * *}\end{array}$ & $\begin{array}{l}-0.013 \\
(2.40)^{* * *}\end{array}$ & $\begin{array}{c}0.084 \\
(18.95)^{* * *}\end{array}$ \\
\hline Regulation & $\begin{array}{l}-0.022 \\
(3.04)^{* * *}\end{array}$ & $\begin{array}{l}-0.012 \\
(2.15)^{* *}\end{array}$ & $\begin{array}{l}-0.021 \\
(2.59)^{* * *}\end{array}$ & $\begin{array}{c}-0.003 \\
(0.45)\end{array}$ \\
\hline Constant & $\begin{array}{c}0.159 \\
(1.53)\end{array}$ & $\begin{array}{c}3.548 \\
(43.68)^{* * *}\end{array}$ & $\begin{array}{l}0.310 \\
(2.54)^{* * *}\end{array}$ & $\begin{array}{c}2.989 \\
(27.35)^{* * *}\end{array}$ \\
\hline $\begin{array}{l}\text { Adjusted } R^{2} \\
\text { No. of observations }\end{array}$ & .89 & 10,532 & .86 & 4,997 \\
\hline
\end{tabular}

Source: IERAL database.

Notes: Absolute value of $z$-statistics in parentheses. Instruments are normal wage_1; output_2; output_3; output_4, consumer price index, capital services price index, wholesale price index, aggregate unemployment index, dce; dca. See table 6A.5 for description of the variables.

***Significant at the 1 percent level.

**Significant at the 5 percent level. 
drops substantially in both equations, with a more dramatic impact on the hours one. Since we measure wages by dividing the wage bill by employment we could have introduced an upward bias in the least square estimates of the labor cost elasticity.

Hours appear less responsive than jobs to fluctuations in costs or scale factors. Theory indicates that with costly changes in manpower, a firm is much more likely to rely on adjustment in hours than on the number of jobs offered. We failed to find support to these arguments, as other studies using quarterly data had previously done (Hamermesh 1993, chap. 7).

When we consider the regulatory burden the results change. To begin with, as regulations get stiffer, employment drops more than hours. That is, firms substitute away from both types of labor: workers and hours. Workers and hours thus appear to be $p$-complements. An increase of 1 percent in the estimated regulatory burden produces a short-run drop in employment of around 0.02 percent, while hours would drop by 0.01 or 0.003 percent (unbalanced and balanced, respectively). This is exactly what we would have expected. As regulations get tighter, firms are more likely to get rid of workers. It is quite remarkable that regulations do have this effect, which is completely counter to that sought by regulators. Job security provisions are typically introduced to protect workers, yet they tend to reduce the number of jobs and increase only in the margin the effort demanded from those who can preserve theirs.

To summarize, upon impact, the presence of regulations seems disturbing for the behavior of the labor market. Theoretically, in the presence of high fixed costs firms could substitute away from labor into capital or other inputs. Yet, while firms have to pay the additional hours at the overtime rate $\left(+50\right.$ percent $/+100$ percent) plus proportional payroll taxes,${ }^{34}$ the expected severance payments are invariant since the regulation recognizes the straight-time rate as the severance cost. Hence, the theoretical elasticity prediction is ambiguous..$^{35}$ Our results suggest that an increase in the regulatory burden reduces the employment-hours ratio somewhat. But the negative effect on total workers and hours employment indicates substitution away from labor.

\section{Robustness}

The cost of severance was calculated using sector-specific data. It is possible, however, that some sectors with low employment levels might also show high turnover rates. Under those circumstances, the cost of severance would be high and a spurious negative correlation might develop. The less

34. Table 6.2 showed that 92 percent of nonwage labor costs are social security contributions proportional to wages.

35. The long-run trade-off between jobs and standard hours has been difficult to find in the literature. See Hamermesh (1993). 
time variability the index of regulations shows, the more severe the problem could be. That is, when most of the regulation variability comes from the between component across sectors, other unobserved components could explain the sign and size of the estimated coefficient.

To check for the existence of spurious correlation we run our labor demand equations on an aggregate index of regulations. That is, we recalculated the index of regulation for the whole of manufacturing. Now the index becomes

$$
\operatorname{Regs}_{t}=\text { Taxes }_{t}+\mathrm{ESP}_{t}=U_{t} \cdot F_{t} \cdot T_{t} \cdot P_{t},
$$

where $U$ is aggregate unemployment rate, $F$ is the fraction of the unemployed that were laid off, $T$ is average tenure, and $P$ is the probability of having severance payment (the percentage of formal wage earners over total wage earners). The results are reported in table 6.9.

Little changes from the results previously reported. The wage elasticity is somewhat lower but roughly equivalent. The output elasticity remains the same. Lagged terms remain invariant as well, insuring that the dynamics will look the same. Finally, the impact of regulations on employment is even stronger than the one previously reported. Now the impact elasticity climbs to 0.09 , a level equivalent to that of wages. The effect on hours appears to dwindle away. The coefficient is now economically and statistically indistinguishable from zero (and the sign becomes positive). Overall, the specification appears robust to this source of spurious correlation.

It would seem appealing to evaluate the differential impact that the different components of the regulatory index have on employment. In table 6.10 we report the results of conducting three exercises. All of them limit the time variability and focus on the cross-sectional factors. The first, which we call option A, holds unemployment and the probability of having been laid off fixed at the mean for the period. Option B assumes that the tenure structure has remained constant over time. Option $\mathrm{C}$ holds unemployment, the fraction of those laid off, and the probability of access to severance payments constant.

Somewhat limiting the time variability of the index of regulations has a very modest effect on our estimates. In all cases, the job elasticity increases. At the same time, hours respond less, turning economically and statistically insignificant. All other parameters remain largely unaffected.

The deleterious effects of regulations on employment seem robust to alternative specifications. Neither restricting the cross section nor restricting the time series variability appears capable of reducing the size or significance of the estimates. In fact, in all cases the impact elasticity increases, sometimes making them equivalent to the wage cost. Conversely, in the case for hours, the effects are weakened. 
Table 6.9

Manufacturing Survey, IV-Endogenous: Wages and Product, Unbalanced Panel (aggregated regulation index)

\begin{tabular}{|c|c|c|}
\hline & $\begin{array}{l}\text { Employment } \\
\text { (1) }\end{array}$ & $\begin{array}{c}\text { Hours per Worker } \\
\text { (2) }\end{array}$ \\
\hline Est. Normal Wage & $\begin{array}{l}-0.097 \\
(-7.834)\end{array}$ & $\begin{array}{l}-0.032 \\
(-3.628)\end{array}$ \\
\hline Est. Output & $\begin{array}{c}0.115 \\
(10.164)\end{array}$ & $\begin{array}{c}0.096 \\
(11.319)\end{array}$ \\
\hline Output_1 & $\begin{array}{l}-0.042 \\
(-6.634)\end{array}$ & $\begin{array}{l}-0.046 \\
(-9.616)\end{array}$ \\
\hline Overtime Wage index & $\begin{array}{c}0.014 \\
(5.019)\end{array}$ & $\begin{array}{c}0.063 \\
(33.478)\end{array}$ \\
\hline Employment_1 & $\begin{array}{c}0.821 \\
(75.662)\end{array}$ & $\begin{array}{l}-0.050 \\
(-6.292)\end{array}$ \\
\hline Employment_2 & $\begin{array}{c}-0.260 \\
(-19.187)\end{array}$ & $\begin{array}{c}0.032 \\
(3.213)\end{array}$ \\
\hline Employment_3 & $\begin{array}{c}0.306 \\
(27.847)\end{array}$ & $\begin{array}{l}-0.048 \\
(-5.846)\end{array}$ \\
\hline Employment_1 & $\begin{array}{c}0.036 \\
(2.763)\end{array}$ & $\begin{array}{c}0.204 \\
(20.923)\end{array}$ \\
\hline Hours per Worker_2 & $\begin{array}{c}0.075 \\
(5.935)\end{array}$ & $\begin{array}{l}-0.028 \\
(-2.951)\end{array}$ \\
\hline Hours per Worker_3 & $\begin{array}{l}0.037 \\
(2.979)\end{array}$ & $\begin{array}{c}0.013 \\
(1.471)\end{array}$ \\
\hline Second quarter & $\begin{array}{l}-0.026 \\
(-5.553)\end{array}$ & $\begin{array}{c}0.123 \\
(32.769)\end{array}$ \\
\hline Third quarter & $\begin{array}{l}-0.027 \\
(-5.508)\end{array}$ & $\begin{array}{c}0.121 \\
(30.734)\end{array}$ \\
\hline Fourth quarter & $\begin{array}{l}-0.020 \\
(-4.074)\end{array}$ & $\begin{array}{c}0.099 \\
(27.156)\end{array}$ \\
\hline Regulation & $\begin{array}{l}-0.091 \\
(-5.545)\end{array}$ & $\begin{array}{c}0.004 \\
(0.291)\end{array}$ \\
\hline Constant & $\begin{array}{c}0.059 \\
(0.580)\end{array}$ & $\begin{array}{c}3.570 \\
(45.026)\end{array}$ \\
\hline $\begin{array}{l}\text { Adjusted } R^{2} \\
\text { No. of observations }\end{array}$ & $\begin{array}{r}0.86 \\
10,532\end{array}$ & $\begin{array}{c}0.68 \\
10,532\end{array}$ \\
\hline
\end{tabular}

Source: IERAL database.

Notes: Absolute value of $z$-statistics in parentheses. Regulation index $=\mathrm{U}$ it $\times \mathrm{Fit} \times \mathrm{T} i t \times \mathrm{P}$ it + taxes, with $i=$ sectors and $t=$ quarters. Instruments are normal wage_1; output_2; output_3; output_4, consumer price index, capital services price index, wholesale price index, aggregate unemployment index, dce; dca. See table 6A.5 for description of the variables.

\subsubsection{Dynamics: The Speed of Adjustment}

So far we have discussed the static, short-run response of employment and hours to changes in wage costs, output, and labor regulations. Next we turn to the adjustment process that firms will follow when one of these variables is shocked. We next present a set of graphs of the dynamic response of firms to 10 percent changes in output, wages, or the costs of regulations. 


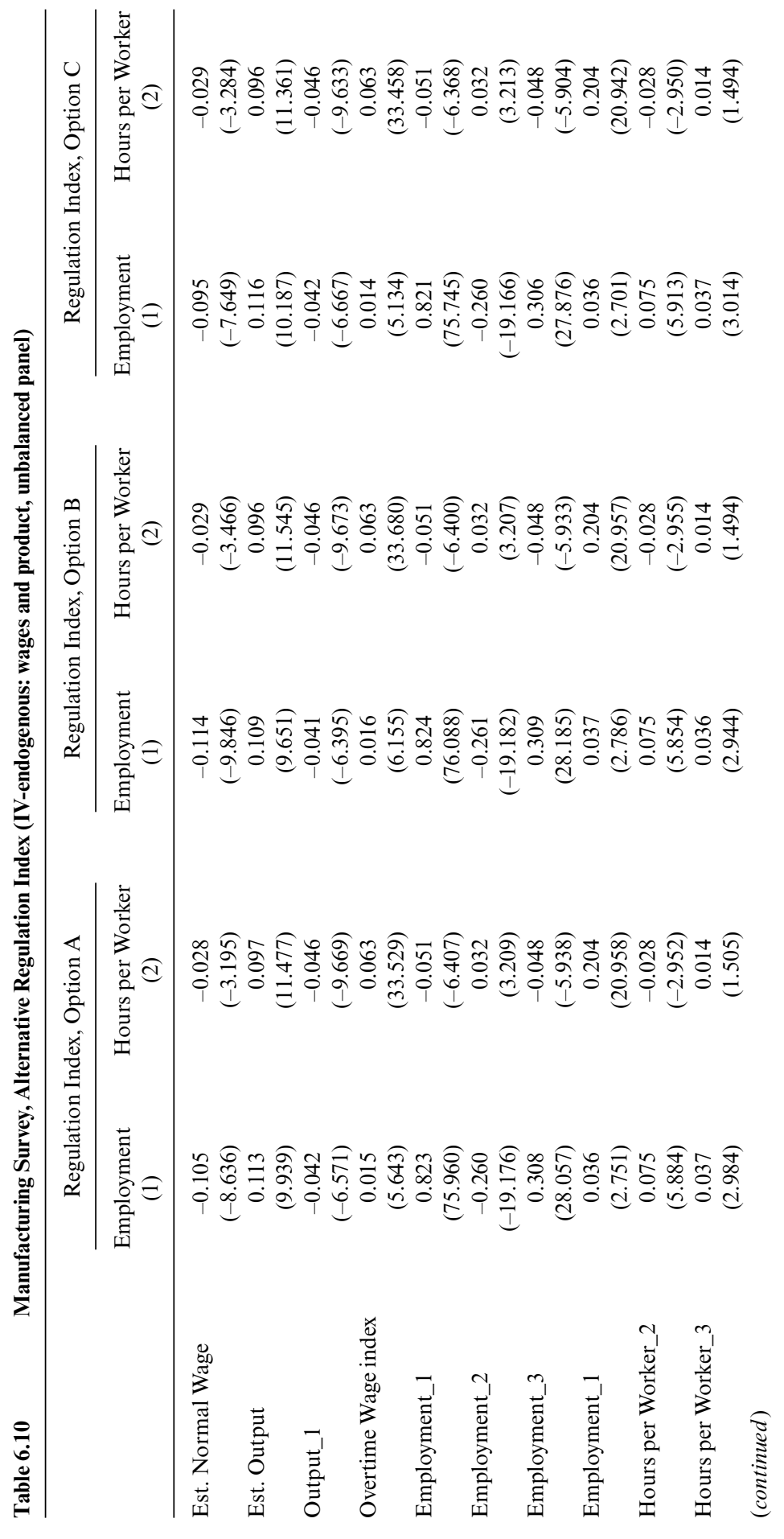









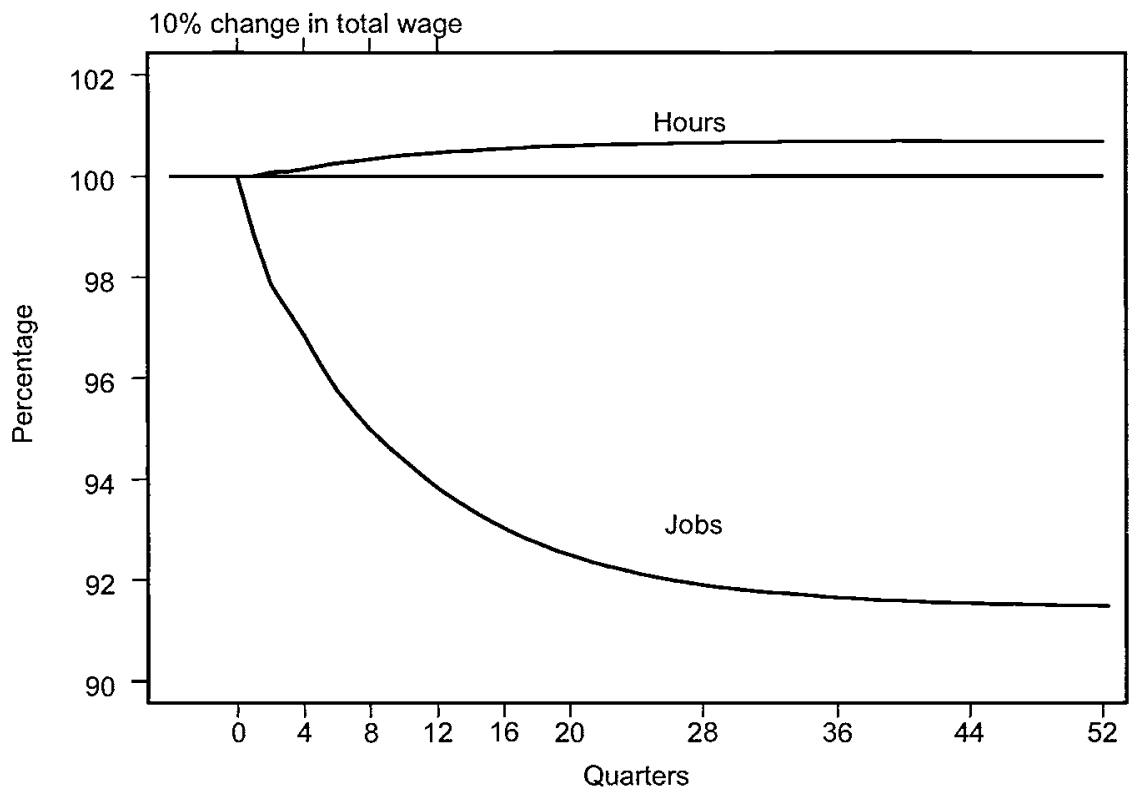

Fig. 6.5 Impulse-response function-change in total wage

Source: IERAL database and table 6.9.



Fig. 6.6 Impulse-response function-change in hourly wage Source: IERAL database and table 6.9. 




Fig. 6.7 Impulse-response function-change in industrial output Source: IERAL database and table 6.9.

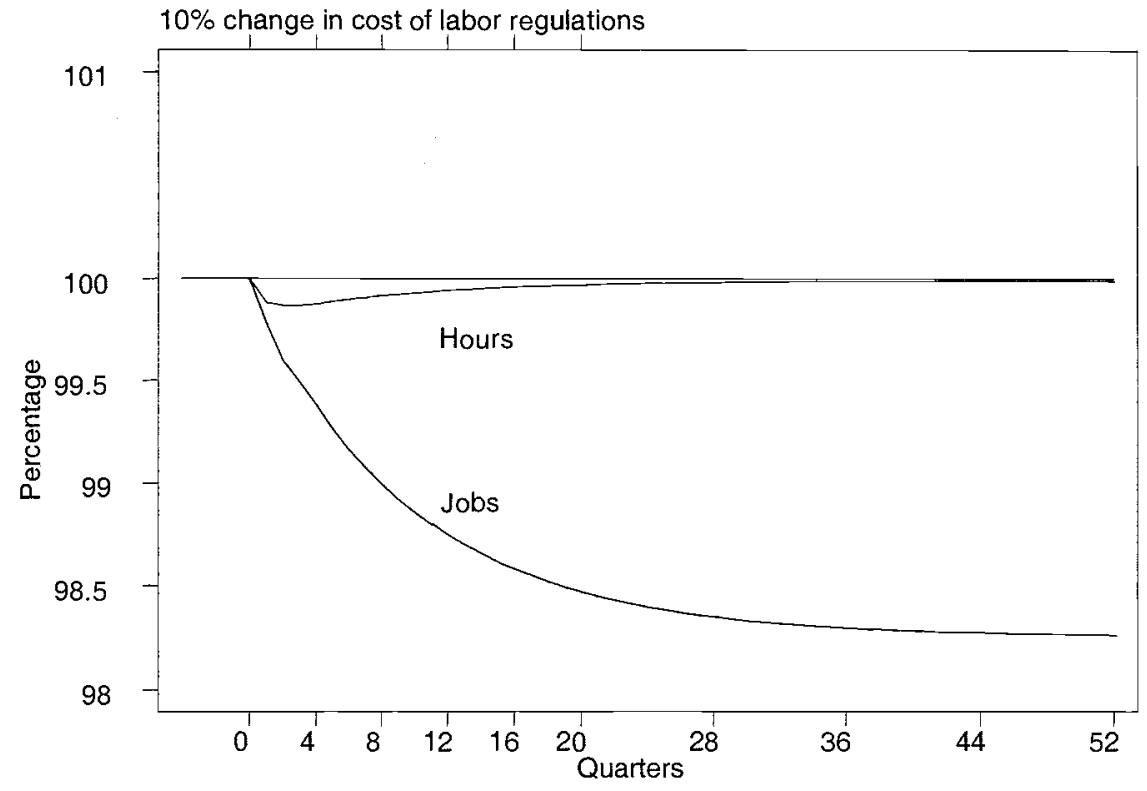

Fig. 6.8 Impulse-response function-change in regulations Source: IERAL database and table 6.9. 
The exercise is conducted based on the regressions previously presented in table 6.8. We selected the unbalanced panel estimates. We allow for the interaction between hours and employment as we shock both equations simultaneously. Figures 6.5 and 6.6 show the response to a 10 percent change in total wages and in hourly wages. Figures 6.7 and 6.8 illustrate the response to a 10 percent increase in output and in regulatory costs.

The median lags are 1.5 and 2.5 years for output and wage shocks. They also illustrate that the response is always greater in employment than in hours. There we observe again the damaging effect of regulations on labor demand. This can only be the case when firms substitute workers in the extensive margin for hours in the intensive one. Firms increase almost 1 percent the hours per worker, while an equivalent increase in wages would have reduced employment 8 percent. The bivariate hours-workers microdata estimation allows us to draw some important conclusions: Regulations do have a negative impact on labor demand, and the impact grows over time.

Another interesting finding is that when we allow for dynamics we find that the response of employment to output is substantially higher than the short-run estimate. While the short-run elasticity is fairly low, the long-run response appears more respectable and close to 0.57 .

Tables 6.11 and 6.12 present the estimated coefficients and long-run responses of hours and employment. For comparison purposes we first reproduce the coefficients from the labor demand model under different assumptions.

Table 6.11 presents estimates of the labor demand elasticity under the different models reported in tables 6.7 and 6.8 and IV-product reported in table 6A.6. The median speed adjustment is among the values reported in Labor Demand Coefficients under Difference Alternatives

\begin{tabular}{|c|c|c|c|c|c|c|}
\hline & \multicolumn{2}{|c|}{ Wage } & \multirow[b]{2}{*}{ Regs } & \multirow[b]{2}{*}{ Output $^{\mathrm{a}}$} & \multirow[b]{2}{*}{$\lambda_{E H}^{\mathrm{b}}$} & \multirow[b]{2}{*}{$\lambda_{H E}{ }^{\mathrm{b}}$} \\
\hline & Total & Hourly & & & & \\
\hline \multicolumn{7}{|l|}{ OLS } \\
\hline Hours & - & -0.197 & 0.031 & 0.038 & - & -0.063 \\
\hline Jobs & -0.151 & - & -0.013 & 0.069 & 0.137 & - \\
\hline \multicolumn{7}{|c|}{ IV: product } \\
\hline Hours & - & -0.193 & 0.021 & 0.077 & - & -0.076 \\
\hline Jobs & -0.173 & - & 0.000 & 0.076 & 0.163 & - \\
\hline \multicolumn{7}{|c|}{ IV: product and wages } \\
\hline Hours & - & -0.022 & -0.012 & 0.058 & - & -0.065 \\
\hline Jobs & -0.118 & - & -0.022 & 0.068 & 0.150 & - \\
\hline
\end{tabular}

Source: IERAL database and tables 6.7, 6.8, and 6A.6.

Note: Dashes indicate data not available.

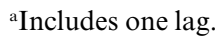

${ }^{\mathrm{b}}$ Includes three lags. 


\begin{tabular}{lcccc}
\hline \multicolumn{3}{c}{ Wage } & & \\
\cline { 2 - 3 } & Total & Hours & Regs & Output \\
\hline OLS & & & & \\
$\quad$ Hours & 0.073 & -0.226 & 0.042 & -0.031 \\
$\quad$ Jobs & -0.946 & -0.208 & -0.049 & 0.603 \\
IV: product & 0.115 & -0.219 & 0.030 & 0.037 \\
$\quad$ Hours & -1.187 & -0.274 & -0.039 & 0.631 \\
$\quad$ Jobs & 0.070 & -0.025 & -0.001 & 0.026 \\
IV: product and wages & 9 & $1^{\text {a }}$ & 1 & $1^{\text {a }}$ \\
$\quad$ Hours & -0.860 & -0.030 & -0.177 & 0.575 \\
$\quad$ Median lags & 7 & 10 & 7 & 6 \\
$\quad$ Jobs & & & & \\
$\quad$ Median lags & & & & \\
\hline
\end{tabular}

Source: IERAL database and tables 6.7, 6.8, and 6A.6.

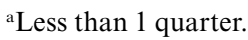

the literature for estimates using quarterly data: 5.5 quarters for jobs and a quicker adjustment for hours. The median for hours adjustment implies a lag on the order of one quarter.

We consider the terms that describe the simultaneous adjustment of employment and hours. We found $\lambda_{E H}>0$ in our specifications suggesting workers and hours to be dynamic $p$-complements. The estimate of $\lambda_{H E}<0$, statistically significant, with absolute values smaller than $\lambda_{E H}$ in our specifications suggesting workers and hours to be dynamic $p$-complements. Results suggest that for a 10 percent long-run decrease in employment there is a 4 percent increase in the demand of hours per worker. The net effect is still a substitution away from labor.

Finally, table 6.12 provides long-run elasticities that can be benchmarked with those previously found with aggregate data (see Montoya and Navarro 1996; Pessino 1995). We found higher values for long-run elasticities. Our results show an output elasticity in the long run of 0.575 percent and 0.03 percent for workers and hours, respectively. The response to wages is also important in the long run, with an estimated employment elasticity of -0.86 percent.

\subsection{Concluding Remarks}

Argentina's experience in the 1990s raises serious questions about the adjustment of the labor market. While output was growing strongly, employment was lagging behind. Many policy observers argued that as the economy demanded greater flexibility to adjust to a more competitive business environment, labor regulations were becoming ever more binding.

We have shown that Argentina's regulations do not quite do what they 
are intended to do. They reverse discriminate provision of protection to those workers with greater human capital. Regulations appeared regressive, limiting the opportunities of those worse off and protecting the jobs of those endowed with higher human capital. We also found that, other things being equal, those who do have regulatory coverage get lower incomes. That is, there is a trade-off between this fringe "benefit" and earnings. The cost, while relatively small, was still significant.

Regulations, and in particular severance payments, represent a cost for business. Firms rationally respond to them by lowering their demand for labor. Indeed, both in the short run and (mostly) in the long run, there is a strong negative effect of regulations on the level of labor demand. This downward shift of labor demand is at least partially responsible for the drop in earnings that is found to be associated with regulatory coverage. Similarly, any downward shift of a demand curve increases the potential for employment reduction.

To compound the problem, our estimates indicate that when regulations become stricter, firms rationally alter their labor allocations. They substitute workers for hours. Indeed, we find that individually worked hours go up with an increased regulatory burden at the same time that the number of workers is reduced. Regulations do not appear to be helpful in creating employment.

\section{Appendix A}

A

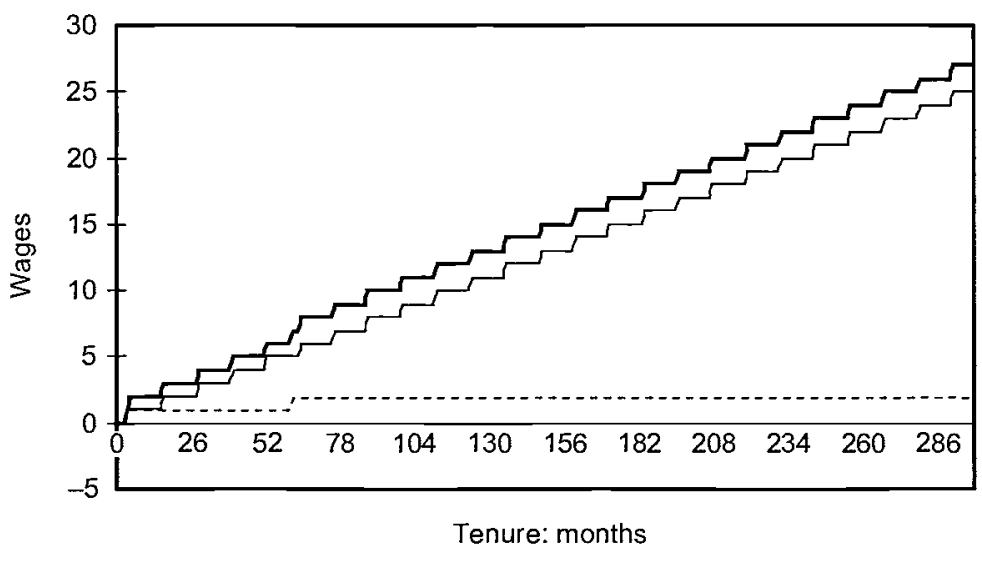

.... Advance notice - Pure indemnity - Total

Fig. 6A.1 Labor regulations regulatory costs: $A$, severance payment; $B$, holiday leave Source: IERAL database, based on legislation enforced in each period. 
B

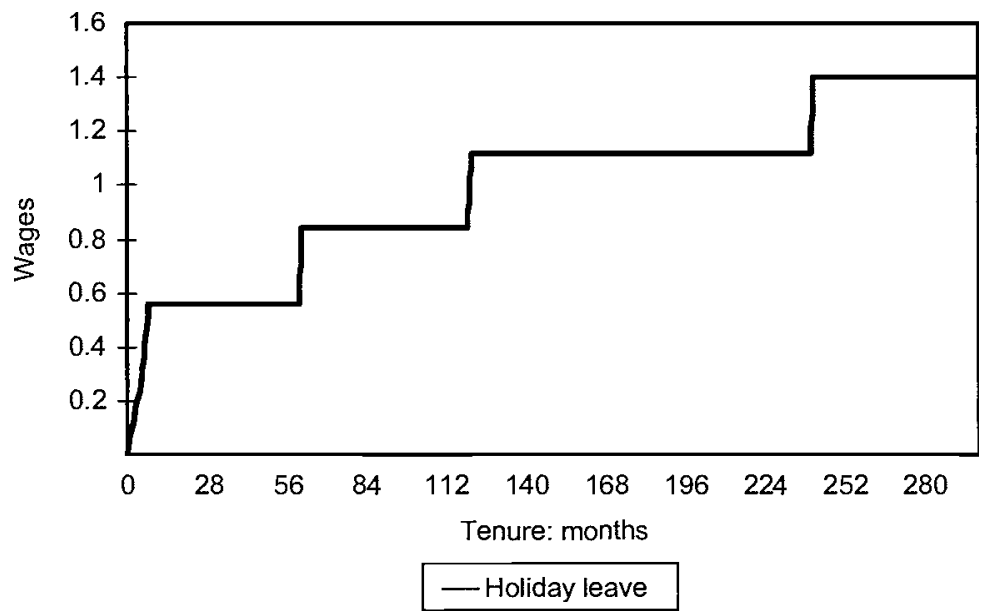

Fig. 6A.1 (cont.) Labor regulations regulatory costs: $A$, severance payment; $B$, holiday leave

Source: IERAL database, based on legislation enforced in each period.

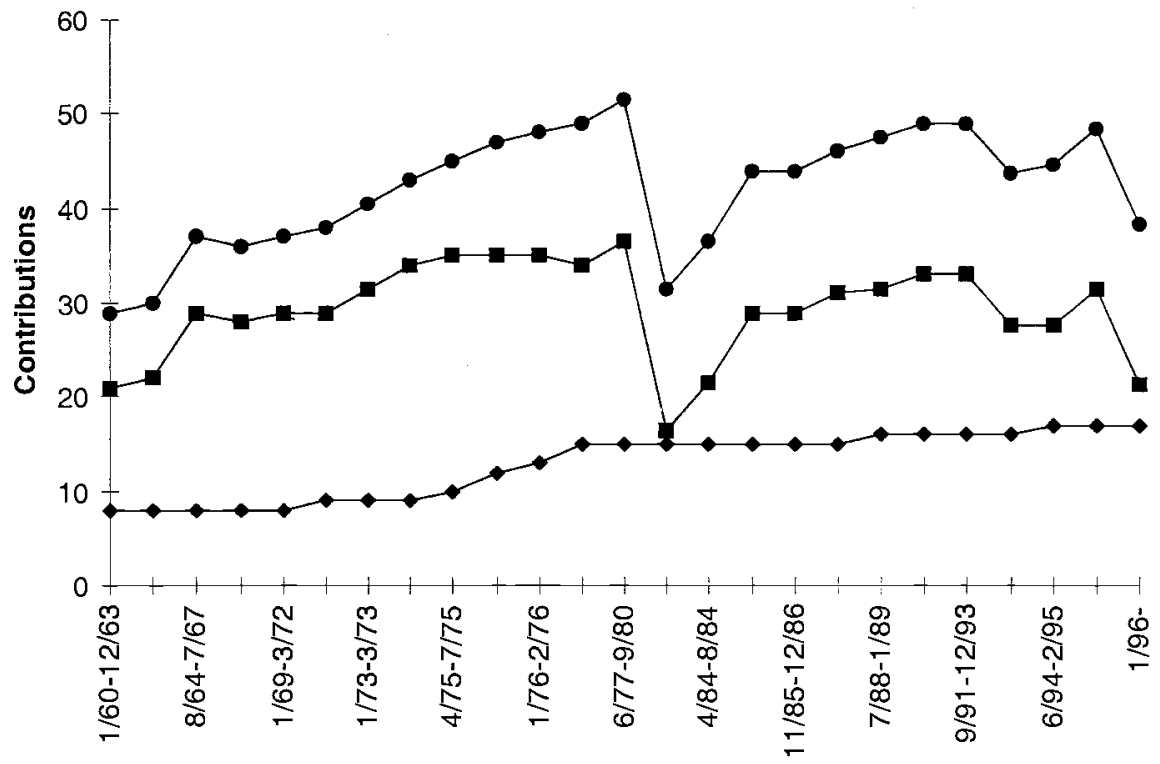

- Total of personal contributions - - Total of employer's contributions Total taxes

Fig. 6A.2 Evolution of the personal and employer contributions to social security as percentage of gross wage 


\section{Appendix B}

\section{Permanent Household Survey}

The microdata data set available to track down the evolution of employment is the Permanent Household Survey (PHS). The PHS survey is a random sample of households that contains an array of personal, demographic, and economic information on individual household members. They are conducted twice a year (in May and October) since 1974 in the main urban centers of Argentina. ${ }^{36}$ The files record information on each respondent's labor market status and living arrangements during the survey week as well as the retrospective data on labor market activity during the previous month.

In terms of personal, demographic, and economic information on individual household members, the following information is available: labor market status (employed, unemployed, or nonlabor force), relation to household head, age, sex, marital status, hours worked in the survey week, occupation, firm size and sector of activity, nonlabor income, schooling, number of children, hourly wage, and number of hours worked. Wage earners declare fringe benefits, making it possible to detect covered and uncovered people. It is not difficult to join personal and household files and to create from these joined databases variables related to households than can influence individual behavior toward the labor market.

The PHS has a rotating sample design, with households (addresses, strictly speaking) in the survey for four waves (two years), with the sample renewed for each wave.

36. Considering the total sample is about 80 percent of Argentina's urban population. It must be remembered that about 15 percent of Argentina's population lives in rural areas (defined as villages of less than 5,000 persons). 


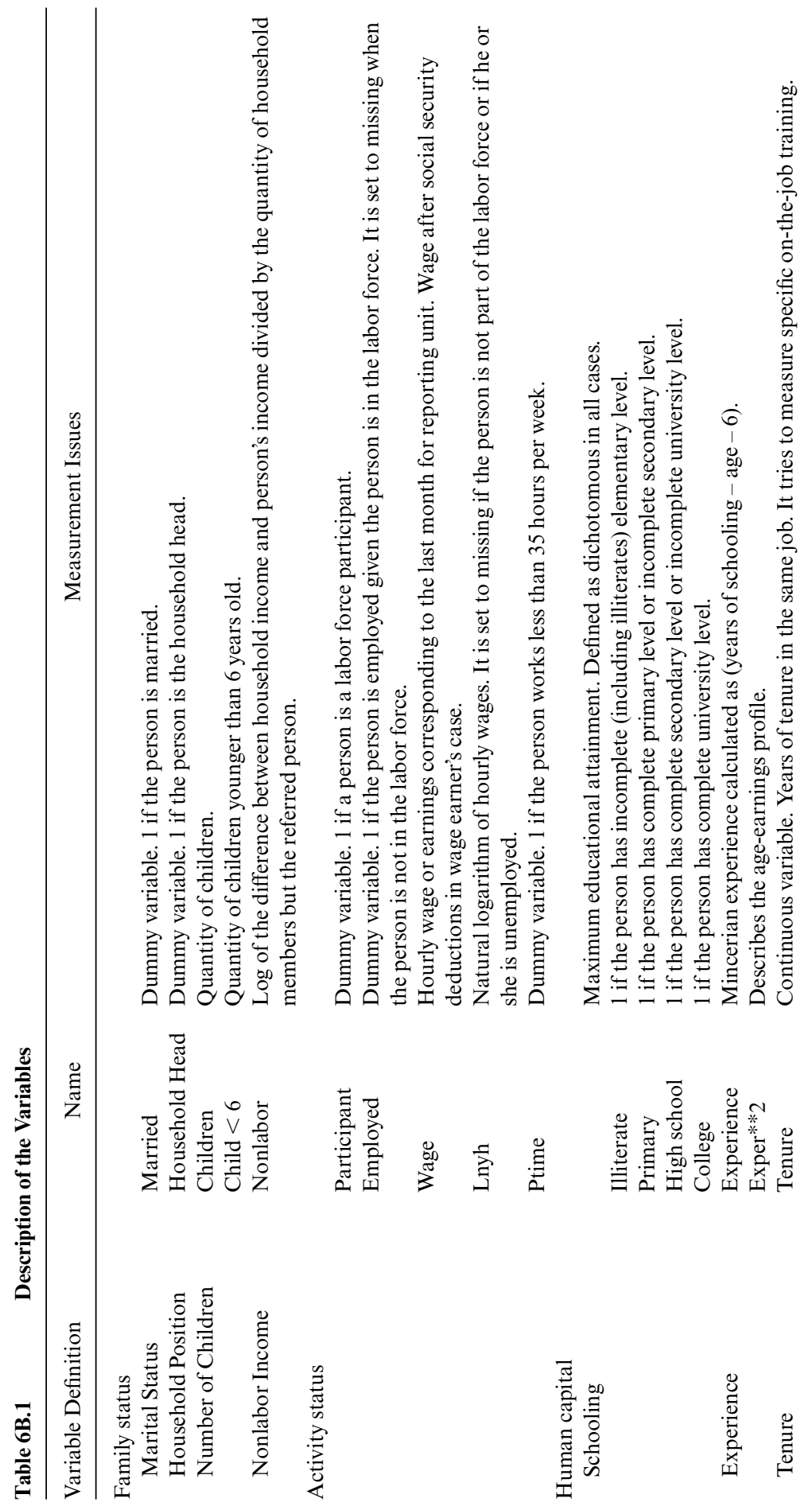




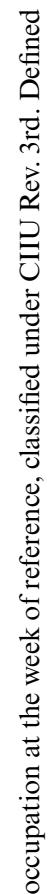

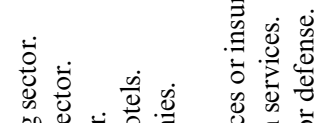

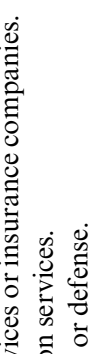

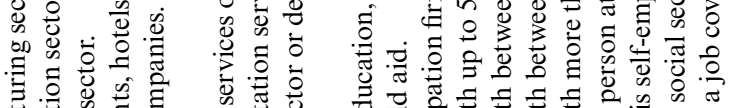

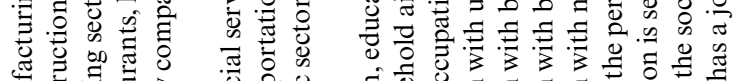




$\Xi \Xi \Xi \Xi \Xi$ $\pm=$ क क क n


क क

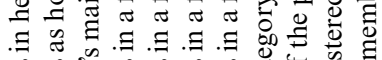

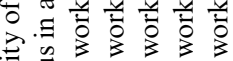

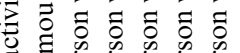

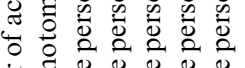

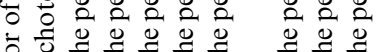

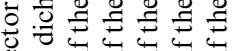
范苛产

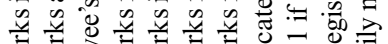

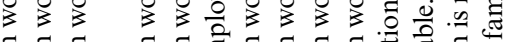

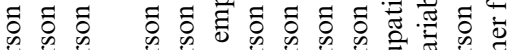

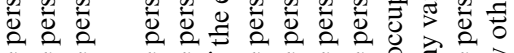
造政: $\rightleftarrows \underset{E}{ \pm}$ Ð

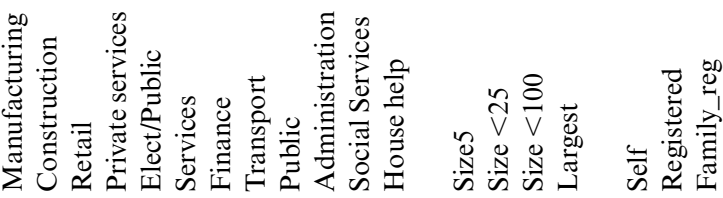




\begin{tabular}{|c|c|c|}
\hline & \multicolumn{2}{|c|}{ Wage Earners } \\
\hline & $\begin{array}{l}\text { Women } \\
\text { (1) }\end{array}$ & $\begin{array}{l}\text { Men } \\
\text { (2) }\end{array}$ \\
\hline Primary & $\begin{array}{c}0.127 \\
(2.14)^{* *}\end{array}$ & $\begin{array}{l}-0.002 \\
(0.07)\end{array}$ \\
\hline High school & $\begin{array}{l}0.609 \\
(9.24)^{* * *}\end{array}$ & $\begin{array}{l}0.330 \\
(7.73)^{* * *}\end{array}$ \\
\hline College & $\begin{array}{c}0.814 \\
(10.59)^{* * *}\end{array}$ & $\begin{array}{c}0.266 \\
(4.43)^{* * *}\end{array}$ \\
\hline Experience & $\begin{array}{c}0.056 \\
(11.82)^{* * *}\end{array}$ & $\begin{array}{c}0.052 \\
(13.48)^{* * *}\end{array}$ \\
\hline Experience**2 & $\begin{array}{l}-0.001 \\
(8.75)^{* * *}\end{array}$ & $\begin{array}{l}-0.001 \\
(11.85)^{* * *}\end{array}$ \\
\hline Tenure & $\begin{array}{l}0.004 \\
(3.58)^{* * *}\end{array}$ & $\begin{array}{l}0.008 \\
(7.07)^{* * *}\end{array}$ \\
\hline Elect & $\begin{array}{c}0.734 \\
(2.15)^{* *}\end{array}$ & $\begin{array}{l}0.461 \\
(3.44)^{* * * *}\end{array}$ \\
\hline Retail & $\begin{array}{l}0.190 \\
(4.16)^{* * *}\end{array}$ & $\begin{array}{l}-0.134 \\
(4.32)^{* * *}\end{array}$ \\
\hline Transport & $\begin{array}{l}0.410 \\
(4.28)^{* * *}\end{array}$ & $\begin{array}{l}-0.205 \\
(5.89)^{* * *}\end{array}$ \\
\hline Finance & $\begin{array}{l}0.380 \\
(6.86)^{* * *}\end{array}$ & $\begin{array}{c}0.050 \\
(1.12)\end{array}$ \\
\hline Service & $\begin{array}{c}0.470 \\
(11.25)^{* * *}\end{array}$ & $\begin{array}{c}-0.018 \\
(0.58)\end{array}$ \\
\hline Size25 & $\begin{array}{c}0.516 \\
(13.54)^{* * *}\end{array}$ & $\begin{array}{c}0.433 \\
(16.59)^{* * *}\end{array}$ \\
\hline Size100 & $\begin{array}{c}1.008 \\
(21.91)^{* * *}\end{array}$ & $\begin{array}{c}0.938 \\
(28.37)^{* * *}\end{array}$ \\
\hline Largest & $\begin{array}{c}1.011 \\
(21.26)^{* * *}\end{array}$ & $\begin{array}{c}1.113 \\
(33.90)^{* * *}\end{array}$ \\
\hline Family_reg & $\begin{array}{c}1.448 \\
(39.67)^{* * *}\end{array}$ & $\begin{array}{c}1.364 \\
(41.86)^{* * *}\end{array}$ \\
\hline Household Head & $\begin{array}{r}0.022 \\
(0.49)\end{array}$ & $\begin{array}{c}0.432 \\
(14.80)^{* * *}\end{array}$ \\
\hline Ptime & $\begin{array}{c}-0.539 \\
(16.55)^{* * *}\end{array}$ & $\begin{array}{l}-0.563 \\
(17.31)^{* * *}\end{array}$ \\
\hline Married & $\begin{array}{l}-0.137 \\
(3.58)^{* * *}\end{array}$ & \\
\hline Child $<6$ & $\begin{array}{r}-0.015 \\
(0.50)\end{array}$ & \\
\hline Constant & $\begin{array}{l}-1.388 \\
(15.55)^{* * *}\end{array}$ & $\begin{array}{l}-1.003 \\
(15.74)^{* * *}\end{array}$ \\
\hline No. of observations & 13,202 & 21,618 \\
\hline
\end{tabular}

Source: IERAL database.

Note: Robust $z$-statistics in parentheses.

***Significant at the 1 percent level.

**Significant at the 5 percent level. 


\begin{tabular}{|c|c|c|c|c|}
\hline & Coefficient & Standard Error & $Z$ & $P>z$ \\
\hline \multicolumn{5}{|l|}{ Employed } \\
\hline Primary & -0.079102 & 0.0419559 & -1.885 & 0.059 \\
\hline High school & 0.0753084 & 0.0486756 & 1.547 & 0.122 \\
\hline College & 0.4914512 & 0.0753675 & 6.521 & 0 \\
\hline Experience & 0.0177675 & 0.0051296 & 3.464 & 0.001 \\
\hline Experience $^{* * 2} 2$ & -0.0001513 & 0.0001033 & -1.466 & 0.143 \\
\hline Children & 0.0107576 & 0.0137898 & 0.78 & 0.435 \\
\hline Child $<6$ & -0.035998 & 0.0240721 & -1.495 & 0.135 \\
\hline Constant & 1.063247 & 0.1024139 & 10.382 & 0 \\
\hline \multicolumn{5}{|l|}{ Probability of participation } \\
\hline Primary & -0.1724532 & 0.0177661 & -9.707 & 0 \\
\hline High school & 0.1627323 & 0.0202538 & 8.035 & 0 \\
\hline College & 0.9491935 & 0.0301072 & 31.527 & 0 \\
\hline Experience & 0.059959 & 0.0017564 & 34.138 & 0 \\
\hline Experience $^{* * 2} 2$ & -0.0014007 & 0.0000328 & -42.723 & 0 \\
\hline Children & -0.1488518 & 0.0050678 & -29.372 & 0 \\
\hline Household Head & 0.8155764 & 0.0198255 & 41.138 & 0 \\
\hline Nonlabor & -0.0000649 & 0.0019907 & -0.033 & 0.974 \\
\hline Constant & -0.4423268 & 0.0261064 & -16.943 & 0 \\
\hline /athrho & -0.0956706 & 0.0812272 & -1.178 & 0.239 \\
\hline Rho & -0.0953798 & 0.0804883 & & \\
\hline Log likelihood & $-3.61 e+07$ & & & \\
\hline Censored observations & 34,291 & & & \\
\hline Uncensored observations & 24,235 & & & \\
\hline Wald $\chi^{2}(7)$ & 208.54 & & & \\
\hline Prob $>x^{2}$ & .0000 & & & \\
\hline
\end{tabular}

Source: IERAL database. 


\begin{tabular}{|c|c|c|c|c|}
\hline & Coefficient & Standard Error & $Z$ & $P>z$ \\
\hline \multicolumn{5}{|l|}{ Employed } \\
\hline Primary & 0.1316827 & 0.0291969 & 4.51 & 0 \\
\hline High school & 0.3709243 & 0.0366284 & 10.127 & 0 \\
\hline College & 0.6478144 & 0.0576389 & 11.239 & 0 \\
\hline Experience & 0.0185666 & 0.0036929 & 5.028 & 0 \\
\hline Experience**2 & -0.0001938 & 0.0000677 & -2.861 & 0.004 \\
\hline Children & 0.0075412 & 0.0094311 & 0.8 & 0.424 \\
\hline Child $<6$ & 0.0625686 & 0.019189 & 3.261 & 0.001 \\
\hline Constant & 0.9992917 & 0.0478594 & 20.88 & 0 \\
\hline \multicolumn{5}{|l|}{ Probability of participation } \\
\hline Primary & -0.0951961 & 0.0286152 & -3.327 & 0.001 \\
\hline High school & 0.1236844 & 0.0349269 & 3.541 & 0 \\
\hline College & 0.3313181 & 0.0650153 & 5.096 & 0 \\
\hline Experience & 0.1497022 & 0.0028334 & 52.836 & 0 \\
\hline Experience**2 & -0.0030261 & 0.0000478 & -63.361 & 0 \\
\hline Children & 0.0727816 & 0.0098712 & 7.373 & 0 \\
\hline Household Head & 0.717768 & 0.027059 & 26.526 & 0 \\
\hline Nonlabor & -0.005561 & 0.0027943 & -1.99 & 0.047 \\
\hline Constant & -0.3758164 & 0.0383718 & -9.794 & 0 \\
\hline /athrho & -0.5661471 & 0.067164 & -8.429 & 0 \\
\hline Rho & -.5125241 & .0495213 & -0.6029607 & -0.4090819 \\
\hline Log likelihood & $-2.26 \mathrm{e}+07$ & & & \\
\hline Number of observations & 49,152 & & & \\
\hline Censored observations & 7,994 & & & \\
\hline Uncensored observations & 41,158 & & & \\
\hline Wald $\chi^{2}(7)$ & 273.54 & & & \\
\hline Prob $>\chi^{2}$ & 0.0000 & & & \\
\hline
\end{tabular}

Source: IERAL database.

\section{Appendix C}

\section{INDEC Industrial Survey: Methodology}

The source of data for the preparation of the indexes of physical volume, workers employed, hours worked, and wages per worker is the Monthly Industrial Survey carried out by INDEC on a total of 1,271 industrial establishments. It is a countrywide sample selected from the third stage of the 1985 National Economic Census. The universe consists of establishments employing more than ten workers and covers all of manufacturing. Complementary data are also provided for public and private institutions.

The survey consists of two questionnaires (A and F), which are answered by the same group of establishments. Questionnaire (A) registers data on jobs, timetables, and wages, while $(\mathrm{F})$ registers product information — phys- 
Table 6C.1

Description of Variables Used in Manufacturing Survey Analysis (INDEC Industrial Survey)

\begin{tabular}{|c|c|c|}
\hline Variable Definition & Name & Measurement Issues \\
\hline \multirow{5}{*}{ Employment and hours } & Employment & Log of manufacturing employment index. \\
\hline & Employment_k & "Linem" lagged $k$ periods. \\
\hline & Hours per Worker & Log of hours per worker index. \\
\hline & Hours per Worker_k & "Linhe" lagged $k$ periods. \\
\hline & Linhag & Log of agency hours personnel index. \\
\hline \multirow[t]{4}{*}{ Wage and labor cost } & Normal Wage & $\begin{array}{l}\text { Log of normal wage index (without overtime } \\
\text { hours). }\end{array}$ \\
\hline & Overtime Wage & Log of overtime hours wage index. \\
\hline & Hourly Wage & Log of hourly wage index. \\
\hline & Regulation & $\begin{array}{l}\text { Log of labor regulations index. The index is } \\
\text { based on severance payment (sector average } \\
\text { tenure } \cdot \text { sector average lay-offs) plus payroll } \\
\text { taxes. }\end{array}$ \\
\hline \multirow[t]{2}{*}{ Product and production } & Output & Log of production index. \\
\hline & Output_k & "Linpf" lagged $k$ periods. \\
\hline \multirow[t]{9}{*}{ Instrumental variables } & Linpbi & Log of GDP index. \\
\hline & $\begin{array}{l}\text { Unemployment } \\
\text { Aggregate Index }\end{array}$ & Log of aggregate unemployment index. \\
\hline & Lni_gram & $\begin{array}{l}\text { Log of economic openness index ([import }+ \\
\text { export]/GDP) by sector. }\end{array}$ \\
\hline & $\begin{array}{l}\text { Physical Capital Price } \\
\text { Index }\end{array}$ & Log of physical capital price index. \\
\hline & Consumer Price Index & Log of consumer price index. \\
\hline & Wholesale Price Index & Log of wholesale price index. \\
\hline & Dcb & $\begin{array}{l}\text { Dummy equal to } 1 \text { if output growth was less } \\
\text { than } 2.7 \% \text { by quarter. }\end{array}$ \\
\hline & Dce & $\begin{array}{l}\text { Dummy equal to } 1 \text { if output growth was be- } \\
\text { tween } 2.7 \% \text { and } 4 \% \text { by quarter. }\end{array}$ \\
\hline & Dca & $\begin{array}{l}\text { Dummy equal to } 1 \text { if output growth was greater } \\
\text { than } 4 \% \text { by quarter. }\end{array}$ \\
\hline
\end{tabular}

Source: IERAL database.

ical amounts produced with own and third-party raw materials and dispatches in physical and monetary units - with a specifically designed questionnaire per establishment. Both questionnaires are submitted monthly.

The bulk of the forms are collected by surveyors from INDEC or from the Provincial Statistics Departments according to agreements with INDEC.

Once the survey forms are collected, they are subjected to routine editing and registry in the database; a team of analysts assesses their consistency, missing items are allocated, and then indicators are calculated.

Since the Monthly Industrial Survey began to be taken in January 1990, it was decided to publish the new series with the average of the 1990 indexes as a basis for comparison and to call this year the base year for the sake of simplicity. 


\begin{tabular}{|c|c|c|c|c|}
\hline & \multicolumn{2}{|c|}{ Unbalanced Panel } & \multicolumn{2}{|c|}{ Balanced Panel } \\
\hline & $\begin{array}{l}\text { Linem } \\
\text { (1) }\end{array}$ & $\begin{array}{l}\text { Linhe } \\
\text { (2) }\end{array}$ & $\begin{array}{l}\text { Linem } \\
\text { (3) }\end{array}$ & $\begin{array}{l}\text { Linhe } \\
\text { (4) }\end{array}$ \\
\hline Linsat & $\begin{array}{l}-0.173 \\
(21.79)^{* * *}\end{array}$ & $\begin{array}{l}-0.193 \\
(36.54)^{* * *}\end{array}$ & $\begin{array}{l}-0.121 \\
(13.51)^{* * *}\end{array}$ & $\begin{array}{l}-0.173 \\
(26.51)^{* * *}\end{array}$ \\
\hline Prodh & $\begin{array}{c}0.119 \\
(10.59)^{* * *}\end{array}$ & $\begin{array}{c}0.129 \\
(17.58)^{* * *}\end{array}$ & $\begin{array}{l}0.064 \\
(4.85)^{* * *}\end{array}$ & $\begin{array}{c}0.136 \\
(13.74)^{* * *}\end{array}$ \\
\hline Linpf_1 & $\begin{array}{l}-0.043 \\
(6.86)^{* * *}\end{array}$ & $\begin{array}{l}-0.052 \\
(12.26)^{* * *}\end{array}$ & $\begin{array}{l}-0.030 \\
(3.67)^{* * *}\end{array}$ & $\begin{array}{l}-0.066 \\
(10.39)^{* * *}\end{array}$ \\
\hline Linsae & $\begin{array}{l}0.018 \\
(7.01)^{* * *}\end{array}$ & $\begin{array}{c}0.054 \\
(32.56)^{* * *}\end{array}$ & $\begin{array}{l}0.026 \\
(8.09)^{* * *}\end{array}$ & $\begin{array}{c}0.053 \\
(22.07)^{* * *}\end{array}$ \\
\hline Linem_1 & $\begin{array}{c}0.815 \\
(77.04)^{* * *}\end{array}$ & $\begin{array}{l}-0.079 \\
(11.07)^{* * *}\end{array}$ & $\begin{array}{c}0.888 \\
(59.86)^{* * *}\end{array}$ & $\begin{array}{l}-0.093 \\
(8.24)^{* * *}\end{array}$ \\
\hline Linem_2 & $\begin{array}{l}-0.252 \\
(18.90)^{* * *}\end{array}$ & $\begin{array}{l}0.059 \\
(6.52)^{* * *}\end{array}$ & $\begin{array}{l}-0.297 \\
(15.36)^{* * *}\end{array}$ & $\begin{array}{l}0.080 \\
(5.41)^{* * *}\end{array}$ \\
\hline Linem_3 & $\begin{array}{c}0.307 \\
(28.38)^{* * *}\end{array}$ & $\begin{array}{l}-0.056 \\
(7.60)^{* * *}\end{array}$ & $\begin{array}{c}0.288 \\
(20.13)^{* * *}\end{array}$ & $\begin{array}{l}-0.038 \\
(3.45)^{* * *}\end{array}$ \\
\hline Linhe_1 & $\begin{array}{l}0.047 \\
(3.65)^{* * *}\end{array}$ & $\begin{array}{c}0.208 \\
(23.56)^{* * *}\end{array}$ & $\begin{array}{r}0.027 \\
(1.57)\end{array}$ & $\begin{array}{c}0.270 \\
(20.54)^{* * *}\end{array}$ \\
\hline Linhe_2 & $\begin{array}{l}0.078 \\
(6.20)^{* * *}\end{array}$ & $\begin{array}{c}-0.013 \\
(1.48)\end{array}$ & $\begin{array}{r}0.007 \\
(0.44)\end{array}$ & $\begin{array}{r}0.017 \\
(1.39)\end{array}$ \\
\hline Linhe_3 & $\begin{array}{l}0.038 \\
(3.18)^{* * *}\end{array}$ & $\begin{array}{l}0.017 \\
(2.02)^{* *}\end{array}$ & $\begin{array}{l}0.055 \\
(3.68)^{* * *}\end{array}$ & $\begin{array}{l}0.025 \\
(2.18)^{* *}\end{array}$ \\
\hline $\mathrm{t} 2$ & $\begin{array}{l}-0.031 \\
(6.70)^{* * *}\end{array}$ & $\begin{array}{c}0.093 \\
(29.15)^{* * *}\end{array}$ & $\begin{array}{l}-0.036 \\
(6.90)^{* * *}\end{array}$ & $\begin{array}{c}0.092 \\
(23.26)^{* * * *}\end{array}$ \\
\hline $\mathrm{t} 3$ & $\begin{array}{l}-0.032 \\
(6.53)^{* * *}\end{array}$ & $\begin{array}{c}0.087 \\
(26.06)^{* * *}\end{array}$ & $\begin{array}{l}-0.026 \\
(4.83)^{* * *}\end{array}$ & $\begin{array}{c}0.081 \\
(19.67)^{* * *}\end{array}$ \\
\hline $\mathrm{t} 4$ & $\begin{array}{l}-0.020 \\
(4.24)^{* * *}\end{array}$ & $\begin{array}{c}0.082 \\
(25.73)^{* * *}\end{array}$ & $\begin{array}{l}-0.013 \\
(2.47)^{* * *}\end{array}$ & $\begin{array}{c}0.071 \\
(17.94)^{* * *}\end{array}$ \\
\hline Lnreg & $\begin{array}{l}-0.010 \\
(1.40)\end{array}$ & $\begin{array}{l}0.021 \\
(4.48)^{* * *}\end{array}$ & $\begin{array}{c}-0.008 \\
(1.04)\end{array}$ & $\begin{array}{l}0.017 \\
(2.83)^{* * *}\end{array}$ \\
\hline Constant & $\begin{array}{l}0.279 \\
(2.81)^{* * *}\end{array}$ & $\begin{array}{c}4.051 \\
(56.12)^{* * *}\end{array}$ & $\begin{array}{l}0.479 \\
(4.06)^{* * *}\end{array}$ & $\begin{array}{c}3.512 \\
(37.12)^{* * *}\end{array}$ \\
\hline $\begin{array}{l}\text { Adjusted } R^{2} \\
\text { No. of observations }\end{array}$ & $\begin{array}{c}.90 \\
10,532\end{array}$ & .72 & .87 & .71 \\
\hline
\end{tabular}

Source: IERAL database.

Notes: Instruments are product: linsat_1; linpf_2; linpf_3; linpf_4, lipc, lipk, lipm, lni_uag, dce; dca; wages: linsat_1; linpf_2; linpf_3; linpf_4, lipc, lipk, lipm, lni_uag, dce; dca. See table $6 \mathrm{~A} .5$ for description of the variables. Absolute value of $z$-statistics in parentheses.

***Significant at the 1 percent level.

**Significant at the 5 percent level. 
Table 6C.3 Variables in the Industrial Survey

\begin{tabular}{ll}
\hline Index & Weighting Factor \\
\hline Physical production & Volume value added \\
Workers employed & Workers employed \\
Hours worked & Hours worked \\
Wages per worker & Total wages \\
\hline
\end{tabular}

Source: IREAL database.

Notes: Value added was calculated as the difference between the values of production and intermediate consumption, excluding value added tax (VAT). Workers, hours worked, and total wages correspond to paid staff employed in production processes of categories no higher than that of supervisor.

Table 6C.4 Base Year Weights

\begin{tabular}{llrrrr}
\hline & \multicolumn{1}{c}{$\begin{array}{c}\text { General Level: } \\
\text { Total and Subdivision Wages }\end{array}$} & $\begin{array}{c}\text { Value } \\
\text { Added }\end{array}$ & $\begin{array}{c}\text { Workers } \\
\text { Employed }\end{array}$ & $\begin{array}{c}\text { Hours } \\
\text { Worked }\end{array}$ \\
\hline 3 & General level for industry & 100.00 & 100.00 & 100.00 & 100.00 \\
31 & Foodstuffs, beverages, and tobacco & 22.76 & 24.03 & 24.60 & 21.26 \\
32 & Textiles and leather products & 9.57 & 16.45 & 16.20 & 13.89 \\
33 & Wood, wooden products, and furniture & 1.65 & 4.97 & 4.71 & 2.20 \\
34 & Paper, printers, and publishers & 5.04 & 5.10 & 5.26 & 6.00 \\
35 & Chemicals and petroleum-based products & 29.75 & 10.19 & 10.43 & 12.44 \\
36 & Cement, glass, ceramics, and other & & & & \\
& nonmetallic minerals & 3.59 & 5.64 & 5.74 & 5.57 \\
37 & Basic metals industry & 4.01 & 7.83 & 7.59 & 10.98 \\
38 & Metal products, machinery, and equipment & 22.81 & 25.11 & 24.82 & 27.19 \\
39 & Other manufacturing industries & 0.82 & 0.66 & 0.64 & 0.47 \\
\hline
\end{tabular}

Source: IREAL database.

In the sampling design, a stratified method of optimal allocation was used, making the selection probability for any given establishment vary according to branch of activity and strata. ${ }^{37}$ The indicators for different aggregation levels up to division and general levels are obtained from the most disaggregated results, weighting them according to the percentage share in year 1986 of the variable chosen for each indicator (see table 6C.3).

The percentage share of each division during $1986^{38}$ in the aforementioned indicators is detailed in table 6C.4.

37. The denomination of activity branch is applied to a subgroup of the third revision of the CIIU, or a body of subgroups generally coinciding with the four-digit subgroups of the third revision of the CIIU and, in a few cases, with the three-digit subgroups of the third revision of the CIIU. The strata are two: (1) establishments with between 10 and 200 paid staff, and (2) establishments with more than 200 paid staff.

38. This corresponds to the third stage of the 1985 Economic Census and refers to the universe of establishments with paid staff. 
The Index of Physical Volume of Production (IVF) provides, with quarterly frequency, an approximation to the development of value added at constant prices. It is worth noting that this last measurement cannot be carried out for each year concerned, let alone each quarter, since in order to obtain it one would have to measure its components (production and intermediate consumption values) at current prices and measure the corresponding deflators. This is why the IVF is usually considered to be the best substitute.

However, it is necessary to add the caution that the relationship between value added and production is not constant. As an illustration it may be mentioned that, as from the census data, a drop in this relationship was noticed during the 1986-1993 period. This was basically due to the economy's externalization process, which stemmed from the deep structural change taking place from 1990.

\section{Calculation Procedure}

The main source of data is Form F of the Monthly Industrial Survey. This contains data on the product basket for each establishment surveyed.

In each establishment, the index of physical volume is calculated monthly, relating the value of its monthly production basket at 1986 figures to the value of the same for that year. For establishment $e$ this would give

$$
\mathrm{IVF}_{e}=\left(\frac{\sum_{i} p_{i}^{0} q_{i}^{t}}{\sum_{i} p_{i}^{0} q_{i}^{0}}\right) \cdot 100,
$$

in which sigma covers all products $i$ selected for the establishment, and

$$
\begin{aligned}
& \mathbf{p}^{0}=\text { the } 1986 \text { price vector } \\
& \boldsymbol{q}_{t}^{0}=\text { the vector of monthly amounts for } 1986 \\
& \mathbf{q}_{t}=\text { the amounts in month } t
\end{aligned}
$$

It should be mentioned that vectors $\mathbf{p}$ for prices and $\mathbf{q}$ for amounts correspond to a product basket that represents at least 80 percent of the value of production in each establishment.

In other words, the basic expression of the calculation corresponds to a Laspeyres quantity index. When new products appear, they are incorporated into the calculation, assigning them a zero amount in 1986 and establishing a $\mathbf{p}^{0}$ emerging from the analysis of current prices based on similar products of other establishments - or, if this is not possible, respecting the relative current price relationship for that year. Quarterly indexes are obtained as simple averages of monthly indexes. 


\section{References}

Bentolila, S., and G. Saint-Paul. 1992. The macroeconomic impact of flexible labor contracts, with an application to Spain. European Economic Research 36: 1013-53.

Chambers, J. 1988. Applied production analysis. Cambridge, U.K.: Cambridge University Press.

Garcia, D. 1996. Hyperinflation, stabilization, and structure of wages in Argentina, 1989-1992. University of Chicago, Department of Economics. Mimeograph.

Hamermesh, D. 1986. The demand for workers and hours and the effects of job security policies: Theory and evidence. NBER Working Paper no. 2056. Cambridge, Mass.: National Bureau of Economic Research, October.

. 1993. Labor demand. Princeton, N.J.: Princeton University Press.

Heckman, J. 1979. Sample selection bias as a specification error. Econometrica 47:153-61.

Leibowitz, A. 1983. Fringe benefits in employee compensation. In The measurement of labor cost, ed. J. Triplett. Chicago: University of Chicago Press.

Lucas, R., and P. Fallon. 1991. The impact of changes in job security regulations in India and Zimbabwe. The World Bank Economic Review 5 (3): 395-413.

Maloney, W. 1997. Labor market structure in LDC: Time series evidence on competing views. World Bank. Mimeograph.

1998. Are LDC labor markets dualistic? World Bank. Mimeograph.

Mascollel, A., M. Whinston, and J. Green. 1995. Microeconomic theory. Oxford, U.K.: Oxford University Press.

Montoya, S., and L. Navarro. 1996. La demanda de trabajo en Argentina: Teoría, aplicación y evaluación de una política [Labor demand in Argentina: Theory, application, and policy evaluation]. IERAL Estudios 19, no. 78.

Oi, W. 1962. Labor as a quasi-fixed factor. Journal of Political Economy 70:538-55. .1983. The fixed employment costs of specialized labor. In The measurement of labor cost, ed. J. Triplett, 63-116. Chicago: University of Chicago Press.

Pessino, C. 1995. Determinants of labor demand in Argentina: Estimating the benefit of labor policy reform. CEMA Working Paper no. 114. Buenos Aires, Argentina: Centro de Estudios Macroeconomicos de la Argentina.

Riveros, L., and R. Paredes. 1990. Political transition and labor market reform in Chile. Santiago de Chile: World Bank. Mimeograph.

Rosenweig, M. 1988. Labor markets in low income countries. In Handbook of development economics, vol. 1, ed. H. Chenery and T. N. Srinivasan, 713-62. Amsterdam: North-Holland.

Smith, R., and R. Ehrenberg. 1983. Estimating wage-fringe trade-off: Some data problems. In The measurement of labor cost, ed. J. Triplett, 347-67. Chicago: University of Chicago Press.

Tunalli, I. 1982. A common structure for models of double selection. Social Research Institute. University of Wisconsin, Social Research Institute. Mimeograph.

Varian, H. 1984. Microeconomic analysis. New York: W. W. Norton. 
